\title{
最近の蒸着技術について
}

\author{
沢木司*
}

(昭和 36 年 7 月 22 日 受理)

\section{Advances in Vacuum Evaporation Technique}

\section{Tsukasa SAWAKI}

(Research Laboratory, Matsushita Electronics Corporation)

\section{1. 緒 言}

1912年に Pohl \& Pringsheim は、より純粋かつ新鮮 な金属膜を作ってその光電効果を測定しようという目的 から、薄膜製作技術の一つを考案した。すなおら、周囲

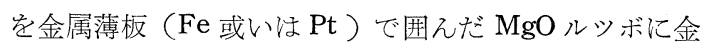
属塊を入れ、真空中 $\left(10^{-3}\right.$ Torr $)$ でこの薄板の通電加熱 によってルッボ内金属を蒸発し、約 $5 \mathrm{~cm}$ 離れたガラス などの下地面に凝結せしめて $\mathrm{Mg}, \mathrm{Al}$ などの一様な薄膜 を得ることができた (5)。これが真空蒸着(以下蒸着と記 す）法の始まりとされているが、その技術的基礎は殆え ぞ1930年代までに確立され (3)、更に、真空技術の飛躍的 進歩に伴って発展して、多くの金属或いは非金属物質に 適用して一様かつ緊密な膜が容易にえられるなどの特徵 から、薄膜製作の最も常識的な方法の一つとして工業的 にも行われるに至った。

蒸着膜の応用洼来特に光学の分野において著るしく 開拓され(1) (4)、反射鏡、反射防止膜その他各 種干涉フ イルターなど科学研究に用いられるもの(これらの使用 波長範囲孔紫外、赤外の領域に拡 げられつつある $\left.{ }^{(6)}\right)$ から、コーテイングを施したカメラ・レンズ、メタライ ズしたプラスチック製品、虹彩色ガラス装身具など我々 庶民生活に関係の深いものまで工場で量産されている。 他方、実験室における単なる技術の一つとして行われて いた分野においても、蒸着法はいつか物性解明の重要な 手段とされるようになって、これらの研究の過程で見出 された新しい事実の応用の意味から、この約十年来蒸着 法はさらに注目を浴び、新しい発展が行われようとして いる。

* 松下電子工業株式会社研究所 (大阪府高槻市大字 西五百住300)
いま二、三の例を拾ってみよう。300〜 $350^{\circ} \mathrm{C}$ に加熱 したガラズ板に 80 パーマロイの組成をもつ厚さ1000〜 $2000 \AA$ 程度の膜を蒸着し、その際下地面に平行に数百Oe の磁場を加えておくと、この磁場の方向に磁化容易方向 をもつ膜となる。この容易方向に外部磁場 $h_{3}$ を加えて 履歴曲線描かすと第 1 図の $h_{\perp}=0$ で示すようにほぼ 角型になる (抗磁力 $h_{c}$ は数 Oe )、つまり二つの安定 (磁化) 状態がえられる。乙かもこの際 $h_{s}$ に垂直な磁 場 $h_{\mathrm{I}}$ を加えると $h_{c}$ も減少して磁化の逆転は容易にな って、それに必要な時間は $0.1 〜 0.01 \mu \mathrm{sec}$ 程度にな $る^{(7)(8)}$ 。このような磁化の逆転は 2 本の互いに直角の 金属リボンを流れる電流で駆動することもでき、これら はすべて蒸着法によって構成することができる。磁性薄 膜のこのような性質は記憶素子、或いはスイッチ回路素:

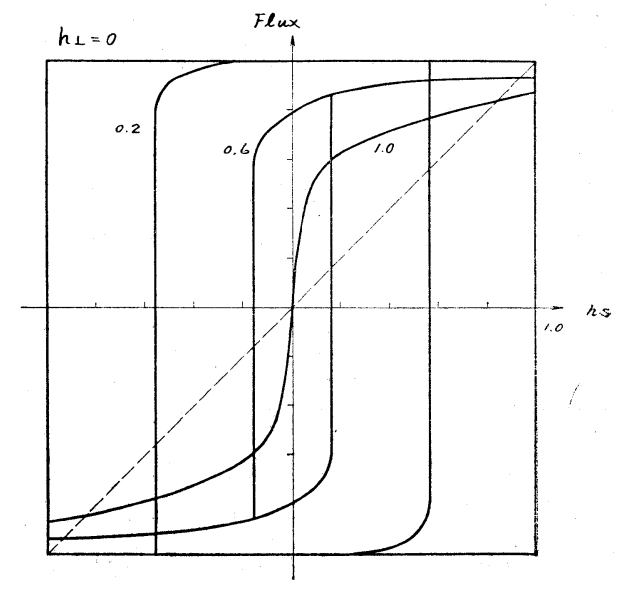

第 1 図 磁性薄膜の理論的履歴 曲線 (Smith)。実線 は外部磁場が磁化容易方向と平行、点線は垂直の場合。 


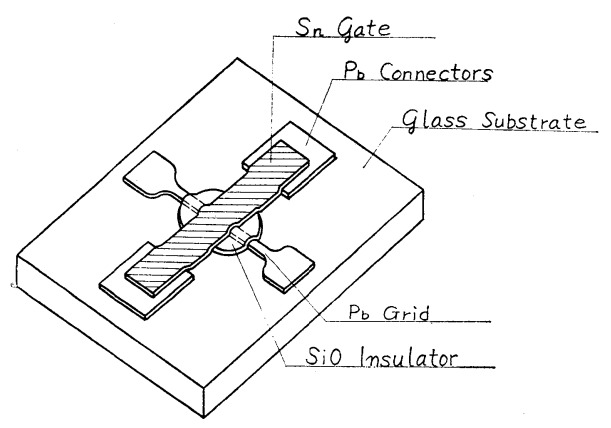

第 2 図薄膜クライオトロン(Newhouse \& Bremer)。

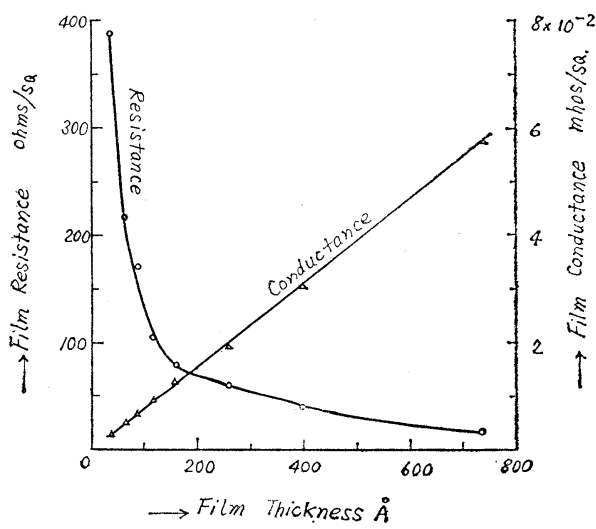

第 3 図 ニクロム膜 $(80 \mathrm{Ni}-20 \mathrm{Cr})$ の抵抗值と膜 厚の関係 (Alderson \& Ashworth)。

子としての広い応用が期待され、また学問的にも興味の あるところで、蒸着磁性薄膜の研究は周知の如く近時す こぶる盛えに行われている(8)・(9)。

また、同じ応用分野に期待されているものに薄膜クラ イオトロンがある。よく知られているように、多くの金 属或いは合金の温度を極低温の領域に下げてゆくと或る 温度 $\left(T_{c}\right)$ 以下で電気抵抗が急激に減少して零になる、 即ち、超電導状態になる。この状態にあるとき $\left(T<T_{i}\right)$ 充分強い磁場 $H_{c}$ を加てやって超電導を破って正常 電導に戻すこともできる。薄膜クライオトロンはこれを 利用したスイッチ回路素子で、その原理的な構成を第 2 図に示す。ダートと呼ぶ $\mathrm{Sn}$ 膜 $(0.3 \mu \times 2 \mathrm{~mm})$ の臨界温 度 $\left(T_{c} \simeq 3.85^{\circ} \mathrm{K}\right)$ より約 $0.1^{\circ} \mathrm{K}$ 低く保ち、これより遙 政界温度が高く超電導状態にあるグリッド $\mathrm{Pb}$ 膜 $\left(T_{\mathrm{c}} \simeq\right.$ $\left.7.22^{\circ} \mathrm{K}, 1 \mu \times 25 \mu\right)$ の電流制御を行って ( $1 \sim 100 \mathrm{~mA}$ 程度), これに誘起された磁場によってゲートの電導状態 を制御するものであって、すべて点着によって作られ る(16)。いまの例では $\mathrm{SiO}$ 絶緑膜の厚さは $0.4 \mu て ゙ 、$ 時定 数〜20 2 secであるが、もっと温度を下げ、絶縁膜を薄 くす机ば数 $\mathrm{m} \mu \mathrm{sec}$ 或いは、そ机以下も可能であるとさ
れている。

部品小型化の要求に適した蒸着抵抗薄膜として最も普 通のものはニクロム膜で(10)’(11)、80 Ni-20 Cr をWボ 一ト $\left(1600^{\circ} \mathrm{C}\right)$ から蒸発して $350^{\circ} \mathrm{C}$ のガラス板に蒸着 し、更にそのまま真空中で $30 \mathrm{~min}$ 加熱しておけば膜は安 定し、その組成はもとの合金と同じで、このようにして

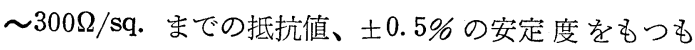
のが可能であるという。その膜厚と抵抗值の実測值を 第3 図に示す(12)。また、ガラス繊維をエポクシ或いは ポリエステル樹脂に埋めたベースにニクロム膜を蒸着し てメラミン・ラッカーで表面保護したものでは〜800 $\Omega /$ sq. までの安定な膜がえられたという報告もあり(12)、 その他、24Cr-76Si なる膜はこのままです空気中で $\sim 250^{\circ} \mathrm{C}$ まで安定で、数百 $\Omega \sim$ 数 $\mathrm{K} \Omega / \mathrm{sq}$. の抵抗值が えられるという報告も見られる(13)。

キャパシター薄膜としては、比較的誘電率の高いZnS 膜も考えられるが、長時間の安定性の点からは $\mathrm{MgF}_{2}$, $\mathrm{SiO}$ などの硬い膜が適しているようである(10)・(11)。厚さ 1 0.1 $\mu$ 程度の $\mathrm{SiO}$ 膜は $200 \sim 250^{\circ} \mathrm{C}$ までかなり安定 で、 $\mathrm{SiO}$ の蒸着を数 $\AA / \mathrm{sec}$ で行えば、数十 $\mathrm{A} / \mathrm{sec}$ の場合 に比べて耐圧、 $\tan \delta$ などが 2 倍 程度良くなって、そ

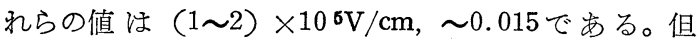
乙誘電率は〜2で、速い蒸着の場合の值の約半 分であ る(14)。 $\mathrm{BaTiO}_{3}$ の蒸着も試みられているが、蒸発中に熱 分解するので、膜を高温 $\left(\sim 1200^{\circ} \mathrm{C}\right)$ て酸化する手続き が必要になる(15)。

以上、近年注目されている応用分野の数例を拾ってみ たが、蒸着技術について従来堆積された事項の1950年代 前半までの殆えどが Holland の成書(4) に納められてい るので、ここでは主としてそれ以後の諸報告の中から蒸 着技術の工夫、改良などを採り上げて簡単に解説を試 み、責を果したい。しかし、筆者は従来主として光学薄 膜の応用の分野で二、三の研究を行って来たのみで、他 の分野についての知識も少く、従って不充分な記述も多 いと思われるが予め御了承願いたい。

さて、或る物質を真空中で加熱蒸発してその蒸着膜 を得るために必要な条件は、よく知られているよう $に^{(3) \cdot(4)} 、$ 次の三項に大別される：

(a) 被蒸発物質自体の熱分解、蒸発源体との反応など が殆えど起らないこと、

(b) 蒸発分子と残留ガス分子との間に衝突、反応など が殆えど起らないとと、

(c) 被蒸着面に達した蒸気分子が凝結して一梯な膜が 形成されるように、下地面は温度が適当でかつ清浄で あること。

以上を実現すべく各種各様の装置が工夫されている。 
それれらの到達真空度は器壁、ガスケットなどのガス放出 量で決まり、10-6 Torr程度までの高真空の金属製蒸着装 置では、毎秒当り蒸着室容積の 5 倍程度の排気速度を有 する拡散ポンプを設備するのが普通である(4)。

上記の条件を念頭に扎いて、大よそ蒸着の手順に従っ て記述を進めるが、超高真空における蒸着、蒸着制御の 方法なぞはそれぞれ一節を当てて後の方で述べる。な お、上記 (a)項が殆えど満足されない場合、(b)項が極め て敏感に影響する場合、或いは、これらに関連して蒸着 後の特殊処理を伴うものなどは余りに煩雑になるのでな るべく触れないととにする。

\section{2. 下地面の清淨化}

下地面の清浄化は溶剂、洗剤、酸などによる予供処理 と、真空容器内でのイオン衝撃、加熱などの方法を適当 に組合わせて行われる(3)・(4)。

予備処理では表面をこすることが有効で、また最後の 水或いは溶剂を一様に除くことが最も厄介である。ガラ ス面のフキ、すなわちアルコールとエーテルの混合液を しませた綿布でふく操作ではこれらを同時に行っている わけであるが、これにはかなりの熟練と、現場では多く の人手を必要とする。これを容易ならしめるため、有機 溶剤或いはこれに界面活性剤を加光て入れた槽に吊した ガラスの面を超音波によって刺戟する方法（これは電気 メッキの際の脱脂工程で既に行わ机ている) が次第に採 り入れられている(10)。そして、とのような処理を施し た㐫とでイオン交換樹脂を通って環流浄化されている水 の槽に入れて洗い、その水の電導度を測って表面清浄度 の目安とする手法を行っている例もみられる ${ }^{(17)}$ 。

予めグロ一放電に曝したガラス面に蒸着した膜がより 強固であることはよく知られているが、放電によって何 か薄い膜がついたり、ガラス面の潜傷が現われることも あり、それらの原因と対策はかなり最近まで解明されて いなかった。他方、拡散ポンプ油やシールに用いるゴム などの蒸気分子は電子衝撃によって容易に分解し、電子 顕微鏡レンズの場合これが污机の原因になることは既に よく知られている(19)。このことに鑑み、Hollandは(18)、 放電に沿ってガラス面を曝す、電極板の穴を通して直接 衝撃する、磁石によって陰極スパッタリングの蔭に曲げ た電子で衝撃するなどを行い（加速電圧 1 〜 $5 \mathrm{kV}$ )，こ の表面の透光率、摩擦係数、呼気像をしらべて、グロー 放電の場合にも陰極暗黑部で加速された電子の衝撃によ ってガラス面に飛来した油分子なぞが分解され、生成物 が附着することを確めた。また、陰極暗黑部で加速され たイオンはこの附着物を除くに充分なエネルギーをもっ

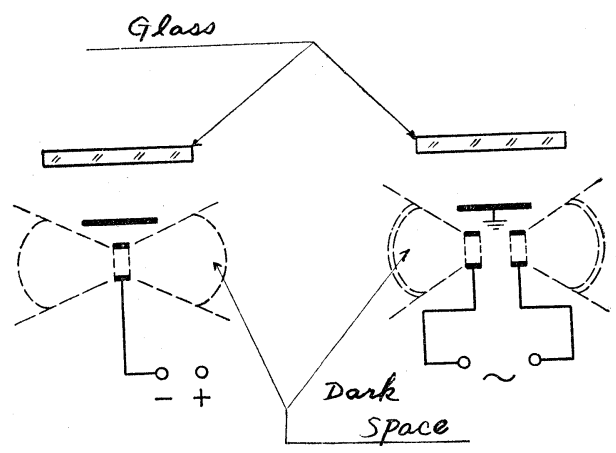

第 4 図 蒸着装置に適したイオン・ボンバード電極 の配列 (Holland)。

ているばかりでなく、更にガラス成分の撰択的なスパッ タリングをともなって多孔性表面層を生ずるに至る。こ れらの結果から、Holland 注結局第 4 図に示すように下 地面浍極暗黒部の蔭において、陽光柱に曝せばよいこ とを示している。

合成樹脂の下地面でる温度上昇に注意すればイオン衝 撃は有益であるとされているが(4)’(18)、先に述べた抵抗 薄膜の実験では、メラミン、シリコン樹脂なぞはイオン 衝撃によって細汃い黾裂が入り易く、エポクシ、ポリエ ステル樹脂、特に、後者が最も耐性に富むと報告されて いる(12)。

また、イオン衝撃注金属面の清浄化に有効で、赤外域光 学材料として用いる $\mathrm{Ge}$ 板 の反射防止膜の蒸着の際に行 われている例も見られる(2n) (Hass \& Turner-Auwärter $\left.{ }^{(2)}\right)$ 。また、半導体表面の測定の際に不活性ガスのイ オン衝撃による清浄法がすこぶる盛えに行われていると とは周知のととと思う。

イオン衝撃によって陰極金属のスパッタされる量も最 近はかなり正確に測られており、充分焼き出しした系を 用いて慎重に行われた実験の結果では、不活性ガスのイ オンによるスパッタリングの割合——(飛散された分子 数) / (イオン数 $)=10^{5} \mathrm{~W} / \mathrm{AIt}$ はほほぼイオンのエネル ギーに比例することが示されている。ここで $W$ 法陰極 から飛散された量(gr.)，A は陰極物質の分子量、I は 陰極電流 (Amp.),$t$ は時間 (sec)を表す ${ }^{(21))(22) 。 と の ~}$ 程度を知っておくために Laegreid \& Wehner がアルゴ ン雰囲気中で行った結果の一部をまとめて第 5 図に示し た ${ }^{(22)}$ 。需囲気”の圧力は $(2 \sim 5) \times 10^{-3}$ Torr, 陰 極温度 $\sim 400^{\circ} \mathrm{C}$, 電流密度 $1 \sim 10 \mathrm{~mA} / \mathrm{cm}^{2}$ の 程 度である。図 の縱軸の $r$ は 2 次電子効果について施すべき補正で、 $\gamma \simeq 0.2$ 程度であろうとされている。上述程度の電流密 度では陰極表面はかなり荒れるが、アルゴン中でGe, Siを 


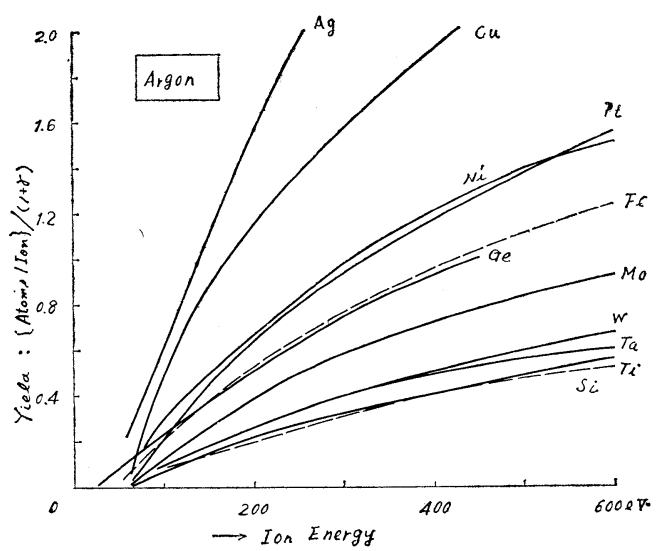

第 5 図 アルゴン・イオンによるスパッタリングの 割合。

イオン衝撃するとき、かなり少い電流密度（～0.1mA $/ \mathrm{cm}^{2}$ ) で温度も室温程度に低くしておけぼ、数時間の 衝撃を行っても全面積の〜95\% が電子顕微 鏡 的にも平 滑であるという. 報告がある(23)。

下地ガラス面を加熱しておくと著るしく強い膜がえら れる場合が多く（ホット・コーテイング）、その理由の 一つとして下地面の清浄化が考えられる。最近 Nielsen は、ガラス面を軟化し始めるまで焰に当てる、真空中で
軟化或いは熔融するまで加熱する方法がよく、特に最後 の方法によって最も清浄な下地面がえられることを示し ている(25)。焰に当てる方法は Mayer等も行っており、こ のような表面は分子の大きさの程度まで平滑であるとい $5^{(65)}$ 。な拉、Nielsen はガラス面の清浄度の判定にTi塊 の尖端をこすりつけて Ti のマークがつくときの最少荷 重を測る方法を試多、従来の呼気像などによる方法（木 下一木内 $\left.{ }^{(2)}\right)$ より遙かに鋭敏な検査法であることを示 し、また Zn を蒸着して膜の模様を見るのもかなりよい 方法であると述べている(25)。すなわら、第1表に示す ように、何等の清浄処理を行わないがラス面では400gr でこすって漸く Tiのマークがつくが、上に述べた最も 清浄な面は $10 \mathrm{gr}$ で既にマークが認められ、清浄化の程 度による差異をかなりよく表示している。これらの下地 面に蒸着した磁性薄膜の特性にも相違が現れ、 $H_{c}$ は先 に述べた抗磁力、 $H_{k}$ 注異方磁場の大きさで、第 1 図で 点線と飽和磁気の交点で表される。

\section{3. 蒸発源}

W，Mo など耐熱金属の線、薄板を用いて目的に従っ て種々の形のヒーターを作り、これに被蒸発物を直接載 せて通電加熱する方法は、蒸発源として最も簡単で、こ れによってこそ蒸着法がその初期の発展を遂げたのであ

第 1 表 ガラス面の清浄度と Ti マーク、磁気特性、Zn 膜模様 (Nielsen)

\begin{tabular}{|c|c|c|c|c|}
\hline 清 浄 方 法 & \begin{tabular}{|} 
Tiマ-ク \\
荷重 (gr)
\end{tabular} & \begin{tabular}{|l} 
抗磁力 \\
$H_{c}(\mathrm{Oe})$
\end{tabular} & $\begin{array}{l}\text { 異方性磁場 } \\
H_{k}(\mathrm{Oe})\end{array}$ & $\mathrm{Zn}$ 膜模様 \\
\hline 1. 清浄せず & 400 & 8 & 8 & 模様多し \\
\hline $\begin{array}{l}\text { 2. 三程化エチンン、アセトン、水、10\%力性ソーダ、濃硝酸、 } \\
\text { 水各10min., 自然乾燥 }\end{array}$ & 100 & $6-7$ & 8 & 模様多し \\
\hline $\begin{array}{l}\text { 3. Teepol (洗剂) 処理、弗酸十ホルマリン、濃硝酸、エタノー } \\
\text { ル、焰乾燥 }\end{array}$ & 50 & $5-6$ & $7-8$ & $\begin{array}{l}\text { アルコールの } \\
\text { 蒸発した場所 } \\
\text { 模様 }\end{array}$ \\
\hline 4. Teepol 処理、弗酸十ホルマリン、自然乾燥 & 100 & $5-7$ & $7-8$ & 模様多し \\
\hline 5. Teepol 処理、弗酸十ホルマリン、エタノール、自然乾燥 & 100 & $5-7$ & $7-8$ & 模様多し \\
\hline $\begin{array}{l}\text { 6. Teepol 処理、弗酸十ホルマリソ、エタノール、エタノール } \\
\text { 蒸気浴 }\end{array}$ & $30-40$ & $3-4$ & $4-6$ & 模様少し \\
\hline 7. 6 の方法+イオン衝撃 $\left(200^{\circ} \mathrm{C}, 1 \mathrm{hr}.\right)$ & $30-40$ & $3-4$ & $4-6$ & 模様少し \\
\hline 8. 6 の方法＋清浄な鹿革で拭く & $60-100$ & $3-4$ & $4-6$ & 線状模様多乙 \\
\hline 9. 6 の方法十赤くなるまで焰に当てる & 30 & $3-4$ & $4-6$ & 模様少し \\
\hline 10. 6 の方法十焰で融かす（縦に保持） & 10 & $|1.5-2.5|$ & $3-4$ & 模様無し \\
\hline 11. 6 の方法十㡜で融かす（水平な炭素支持台上） & 10 & - & - & 模様無し \\
\hline 12. 6 の方法十真空溶融（白金皿上） & 10 & $|1.5-2.0|$ & $2-3$ & 模様無し \\
\hline 13. 真空溶融した鉛一ゲルマニウムガラス & 一 & $|1.3-2.0|$ & $2-3$ & 模様無し \\
\hline
\end{tabular}


る(Strong) $)^{(3)}$ 。なおここで、各種金属の $10^{-8}$ 〜 $10^{3}$ Torr にわたる蒸気圧曲線が Honig によって示されており、 一部は本誌にも描かれているので参照されたい(24)。

さてしかし、このような直接加熱の蒸発源ではヒータ 一金属が多くの実用的金属或いは合金に侵蝕され易く、 膜にも混入することになるので、大量の蒸発をやりたい 場合、極めて純度のよい膜を蒸着したいときには不適当 である。 $\mathrm{Al}$ の大量蒸発源は紙や合成樹脂シートえの連 続蒸着の意味から興味をもたれているのであるが、守屋 は、見掛沙の密度 $1.8 \sim 1.9$, 不純物含有度 $0.05 \%$ 以下 の炭素棒にルツボ孔を岁けた蒸発源を用いて、Alに10\% 或いはそれ以上 $\mathrm{Mo}$ を混ぜて $1500^{\circ} \mathrm{C}$ 程度で蒸発すれ ぼ、蒸発源の寿命も長く、反射率のよい膜がえられるこ とを示している(26)。また、從来炭化物の使用に期待が 寄せられていたのであるが(4)、Holland は、炭素棒又 はルツボに炭化物塊を収容し、 $1500^{\circ} \mathrm{C}$ に加熱した炭化 物表面に $\mathrm{Al}$ 線を送り达导方法を試夕ている(26)。いく つかの炭化物のうち $\mathrm{TaC}$ が最も寿命が長くて、W塊の 場合の 10〜35 倍程度も㐫り、10kW 入力で〜 $1 \mathrm{gr} /$ $\mathrm{cm}^{2} \cdot \min$ の蒸発が可能であるという。田畑等は 2 本の $\mathrm{TiC}$ 棒の先端を普通の耐熱ルッボの中に入れて接触させ ておき、これにA1塊を入れる方法を試みた ${ }^{(27)}$ 。融け た $\mathrm{A} 1$ が棒を這い上って蒸発し、ルツボは全く侵されな いのが特徵で(第 6 図), $2.3 \mathrm{~kW}$ 入力で $0.5 \mathrm{gr} / \mathrm{cm}^{2} \cdot \min の$ 蒸発が可能であるという。

これらの例で寿命とは侵蛆による著るしい変形或いは クラックの生ずるまでの蒸発可能量などを意味している

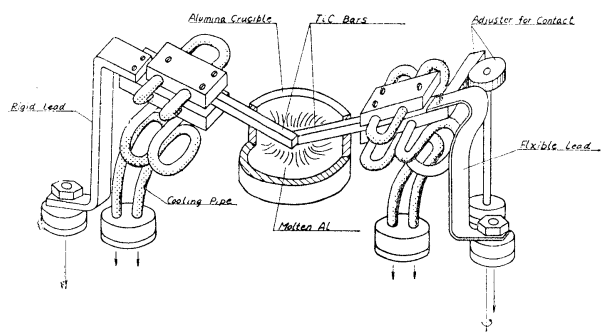

第 6 図 金属の大量蒸発源（田畑氏の好意による）

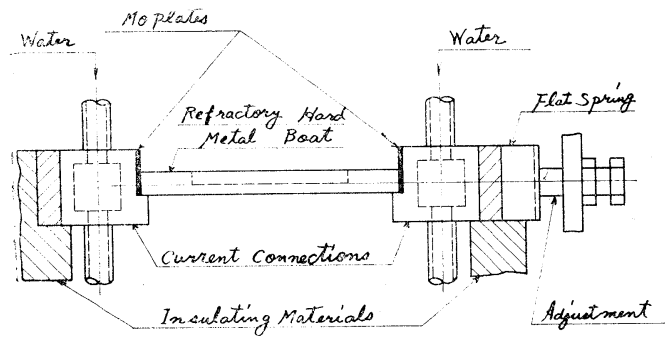

第7図 ハード・メタルのボートを用いた蒸発源

(Metallwerk Plansee カタログ)。
のであるが、Holland は TiC は初めの数分で艘裂が現 れるといっているが、田畑等の結果では 30〜40gr の蒸 発は可能であるという。このような相違は田畑等も指摘 しているように TiC の組成によるものであろう。な 予、炭素棒や耐熱硬質合金棒を用いるときは熱衝撃を避 けるため一端を可動性に保持すべきで、これを簡単な構 成によって行っている一例学第 7 図に示しておく。

$\mathrm{Cu}$ の連続蒸発源には Mo板を用いたものが本誌で報 告されている（大力 $1.7 \mathrm{~kW}$, 蒸発速度 $0.25 \mathrm{gr} / \mathrm{cm}^{2}$ ・ $\min )^{(30)}$ 。志た、上記第 6 図と多少似た方法で、2本の 炭素棒の尖端をスプリングの力で押し合わせて通電すれ ば C膜を蒸着することができ、レプリカの蔭影づけに利 用されていることは周知のことと思らが、炭素に Pt 10〜50\% 混ぜて蒸着した膜は非晶質で粒状 性が少く、 〜10̊の高低まで観察できるという (Bradley) ${ }^{(28)}$ 。C蒸 着膜の組織、電気抵抗などについては Blue 等の詳しい 報告がある(28)。

他方また、化合物の蒸発に際しては熱分解の問題があ り、特に酸化物を通電加熟七一タ一に直接載せると、ヒ ーター金属の酸化とその葬発の現象が加わるのでより複 雑になる。現在実用されている酸化物蒸着膜は二、三の ものに限られているが、それらについて簡単に述べよ 亏。

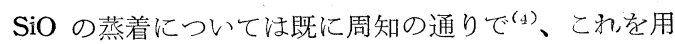
いたキヤパシター膜は第 1 節で触机た。実際に SiO を 蒸着するには Ta ボートを用いるのが普通で、その際粉 末試料は飛散し易く、塊状試料では蒸発し難い不都合が ある。最近 Drumheller 注 8 図に示すような輻射型 蒸発源を用いると好都合に蒸着できることを報告してい る(29)。乙の形式の蒸発源汇 ZnS の蒸着にも既に用いら れている(20)。なお、最近は蒸着用 $\mathrm{TiO}$ 薬品も入手で き、詳しい報告は見当らないが、高屈率膜或いは高誘電 率膜としての応用が期待される。

$\mathrm{Sb}_{2} \mathrm{O}_{3}$ はアルミナで被覆したヒーターを用いると、殆

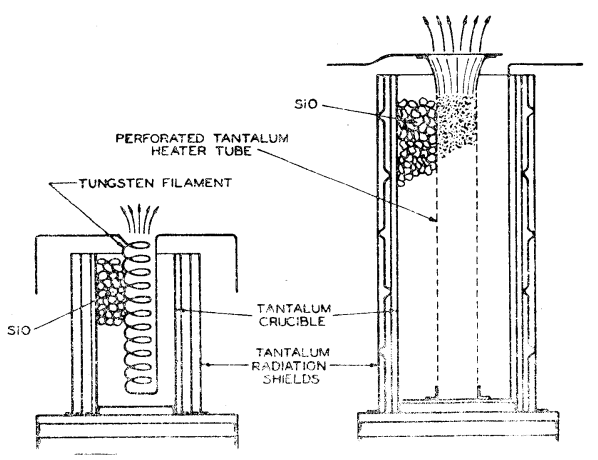

第 8 図杽華する物質に適当な煙突型大量蒸発源 (Drumheller)。 
んど $300 \mathrm{~m} \mu$ まで透明な膜が蒸着され、カメラ・レン ズの色消しコーテイングとして一部に実用されてい

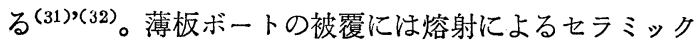
・コーテイングの方法を用い、これにいま一度アルミナ 微粉をごく薄く塗って真空中で熔かしたものが非常に使 いよい(32)。

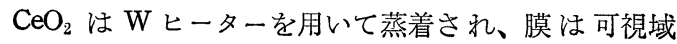
短波長端で僅かの吸収を示すのみで、特に下地ガラス面 が約 $300^{\circ} \mathrm{C}$ のときは屈折率 2.4 程度の極めて硬い膜が えられることが Hass によって示された ${ }^{(33)}$ 。筆者等の 研究では予め $\mathrm{CeO}_{2}$ 薬品を $\mathrm{HCl}$ 溶液で洗うと特に耐水 性、耐酸性のすぐれた膜がえられた ${ }^{(32)}$ 。 $\mathrm{CeO}_{2}$ 膜のこ のすぐれた実用強度は光学薄膜として広く応用されつつ あり、我が国においても現在 $\mathrm{MgF}_{2}$ 膜 と組 合せた虹彩 色装飾品、コールド・ミラーなどに実施されている。

さて、他の型の蒸発源として電子加熱の方法があり、 直流高圧電源など設備が幾分面倒になるので従来は余り 行われていなかったようであるが、蒸発源構成体の污れ の殆えでない膜、高融点金属或い注合金などの膜も蒸着 できることから近年再び注目されるようになった。

電子加熱に用いら礼る電子放射の方式は第 9,10図に 示すように円柱ビームをルッボ内の被蒸発物に当てるす の、環状ビームを線状蒸発物或いはルツボに当てるもの の二つに大別される。前者では比較的長い光路で発散を 防がねばならないので数十 $\mathrm{kV}$ ，の安定化電源を必要之 するが、〜45kV，30mAの衝撃で $\mathrm{Si} ， \mathrm{Pt}$ な゙蒸着し た例がみられる ${ }^{(34)}$ 。これに対して後者の場合は数 $\mathrm{kV} の$ 電源で済み、電圧リップルも余り問題にならないという 利点があって、線の蒸発は先端の熔滴から行われ、そ の蒸発速度は多くの金属について理論式とよく一致す る(38)。2kV, $200 \mathrm{~mA}$ 程度以下で $\mathrm{W}, \mathrm{Ta}$ など高融点金

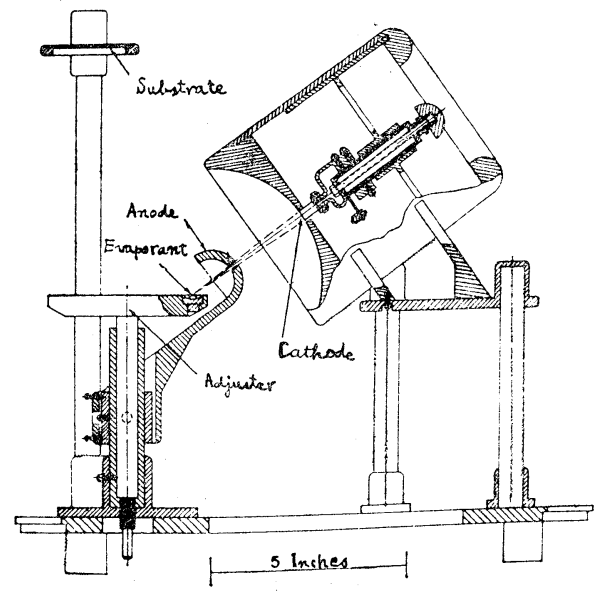

第 9 図 電子加熱蒸発源 (Thun \& Ramsey)。

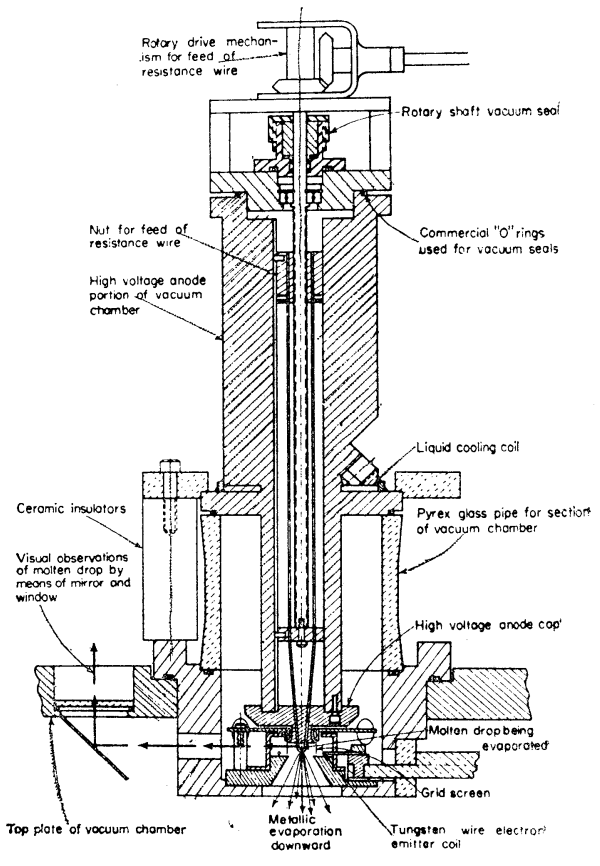

第;0図 電子加熱蒸発源 (Moore)。

属、 $\mathrm{Fe}$ - $\mathrm{Ni}$ 磁性合金、 $\mathrm{Al}_{2} \mathrm{O}_{3}, \mathrm{SiO}_{2}$ など酸化物 の蒸 着が 試みられている(35)。合金線は一定条件で送り込むこと により組成変化の殆えどない純粋な膜がえられ、また酸 化物はとれを取り囲むW補助電極がはじめ加熱され、温 度上昇によって酸化物も導電性となるのでこれに電子が 集中しはじめて熔融、蒸発するという巧妙な工夫がなさ れている(Moore) $)^{(35)}$ 。また第23図を参照されたい。

なお、これら電子加熱它行うに当って注、高電圧を導 入するので $5 \times 10^{-5}$ Torr程度以上の真空度が 必要で、女 た蒸発蒸気の圧力が上昇すると放電を起すので蒸着速度 が制限される（上記 $\mathrm{Fe}-\mathrm{Ni}$ 膜の場合最大 $1500 \AA / \mathrm{min}$ という）。実際の蒸着は㝕からのぞき見て電流、電圧を 調節しながら行っているが、 $10 \mathrm{kV}$ 以上の電圧を用いる ときは当然空にX線の防護を配慮しなければならない。

以上の蒸発源の形式のほかに、高周波加熱の方法はガ ラス製容器の外部から操作もでき、純度のよい金属膜の 蒸着も可能であるなどの利点から古くからしばしば行わ れており、コンデンサー・ペーパーの $\mathrm{Al}$ 連続蒸着を大型 炭素ボートの誘導加熱によって行っている例も筆者は見 た。また、かなり新しい試みとして高真空中における電 孤放電の方法がある。第11図は永田等によるもので(36)、 間渇電孤法は振動電極の接触一離間の際に起る放電によ って陰極物質を蒸発させるものであるが、膜のピンホー ル、表面の荒れなどにまだ改良の余地が残っており、純 


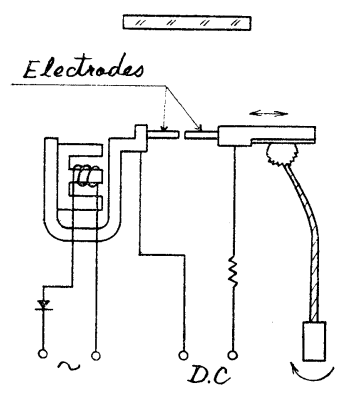

(a)

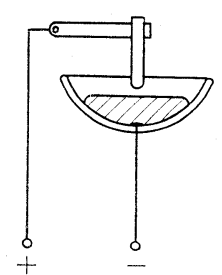

(b)
第11図 電孤放電型蒸発源（永田、他）。 (a) 間渴電孤法、(b) 持続電孤法。
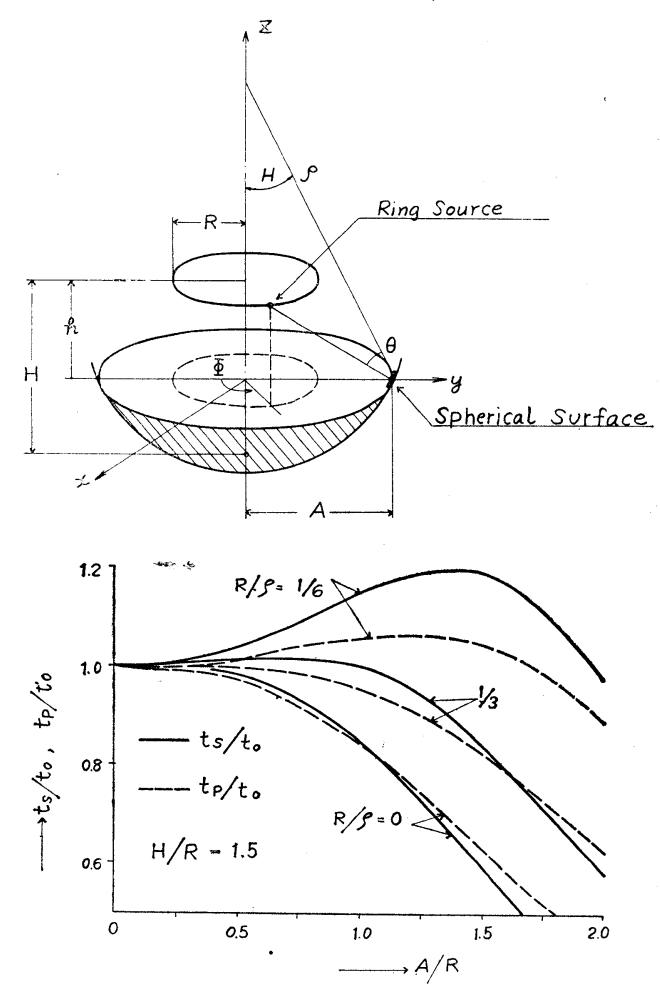

第12図 輪状蒸発源から球内面上に蒸着したときの 膜厚分布。

度のよい膜を得る方法の一つとして期待される。 $\mathrm{Zn}, \mathrm{Sn}$ など蒸気圧の高い金属の膜は持続放電によって蒸着され るが、最近の報告では高融点金属でもこれが可能である という(Lucas, etal) ${ }^{(36)}$ 。

\section{4. 蒸着膜の厚さの分布、マスキング}

蒸着可能の条件が理想的に実現されたとすれば、下地 面上の膜厚の分布は照明の問題に類似して、点蒸発源は
点光源と、平面蒸発源は拡散発光面と同等に取扱うこと ができる。この仮定にもとづいてリボン状、円柱状、輪 状蒸発源 (下地面の回転) などから平面上に蒸着する場 合の厚さの式は Holland 等により詳しく計算されてい $3^{(4) \cdot(37)}$ 。

筆者は球内面上光の分布の式を計算してみたので、そ の結果のみを述べておく ${ }^{(32)}$ 。第12図上部に示す輪状蒸 発源の配列では

$$
r^{2}=h^{2}+(R+A)^{2}-4 R A \sin ^{2}(\Phi / 2), \cos \varphi=h / r
$$$$
\cos \theta=\{h \cos \Theta+(A+R \cos \Phi) \sin \Theta\} / r
$$

の関係があるから、これを点蒸発源の膜厚の式に代入し て積分すれば、結局、点蒸発源が輪状に並ぶときの膜厚 は、蒸発総量 $m(\mathrm{gr})$, 密度 $\delta$ として

$$
\begin{gathered}
t_{\mathrm{p}}=\frac{m}{2 \pi^{2} \delta}\left\{h^{2}+(R+A)^{2}\right\}^{-3} / 2\left[\left\{\frac{h \cos \Theta+(R+A) \sin \Theta}{1-k^{2}}\right.\right. \\
\left.\left.-\frac{2 R \sin \Theta}{k^{2}\left(1-k^{2}\right)}\right\} \mathrm{E}(\pi / 2, k)+\frac{2 R \sin \Theta}{k^{2}} \mathrm{~F}(\pi / 2, k)\right]
\end{gathered}
$$

ここで函数 $\mathrm{F}, \mathrm{E}$ 和第 1 種及び第 2 種の楕円積分を表し、

$$
k=4 R A /\left\{h^{2}+(R+A)^{2}\right\}
$$

で与えられる。また輪帯状蒸発源の場合には

$$
t_{\mathrm{S}}=\frac{m h}{\pi \delta} \cdot \frac{\left(h^{2}+R^{2}+A^{2}\right)(h \cos \Theta+A \sin \Theta)-2 A R^{2} \sin \Theta}{\left\{h^{2}+(R+A)^{2}\right\}^{3 / 2}\left\{h^{2}+(K-A)^{2}\right\}^{3 / 2}}
$$

がえられる。これらの式で $\Theta \rightarrow 0, \theta \rightarrow \varphi$ とおけば従来 の平面上の厚さの式と一致する。第12図下部の曲線は $H / R=1.5$ の場合の分布 $t_{\mathrm{p}} / t_{\mathrm{o}}, t_{\mathrm{s}} / t_{\mathrm{o}}$ を示し、 $t_{\mathrm{o}}$ は中 心軸との交点における厚さを表す。これらの式は小物の 多数を蔒着する場合の膜厚分布の検討に用いられる ${ }^{(32)}$ 。

実際の膜厚分布が理論值とかなりよく一致することは 多くの実験で確められており、広い平面上で一様な膜厚 分布を得るために二つ或いはそ和以上の蒸発源を並 べる、更に下地面を迴転するなどの工夫も行わ机てい る(37)。しかし、特にコイル状フイラメントなどから少 量の蒸発を行う場合には著るしい影を生ずることがあ り、Preuss は、 $\mathrm{Au}^{198}, \mathrm{Cr}^{51}$ など放射性同位元素を蒸着 して極く薄い膜の厚さの分布を測定してこのことを指摘 している。彼は更に、蒸着をピンホール（直径 $75 \mu$ 或い は $125 \mu$ )通して行い(この考えは Strongが $\mathrm{Al}$ の蒸 発で既に行っている(3) ）、その極く薄い膜（平均～10-2 Å程度と称する) の像を放射線写真にとって蒸発源の 模様を示した ${ }^{(39)}$ 。例えば、Au に高温になると表面張力によって低温部に引張られてむ しろ低温部からの蒸発総量が多くなり、Crをコイル状 フイラメントから蒸発する場合はヒーターに接する所で 融けた $\mathrm{Cr}$ がュイル内側を間歇的に這い上り、コイル線 


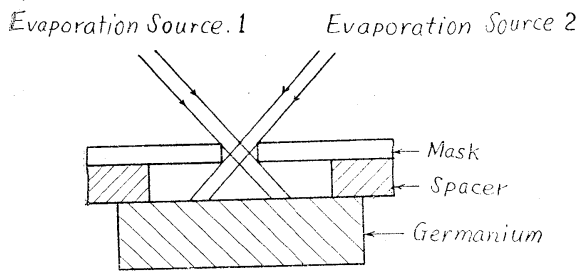

(a)

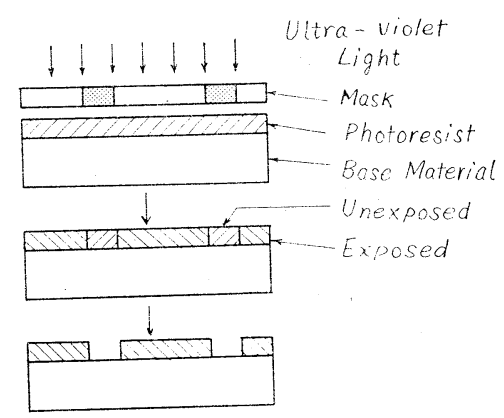

(b)

第13図 蒸着のマスキング。

(a) Mesaトランジースタの場合のマスキング。

(b) 写真的手法によるマスキング。

外側からの蒸発は起らないなぞの議論定行っているが、 一回の蒸発で起るすべての変化の重った写真で論議して いるのであいまいな点も多い。

ここで次に、蒸着の遮蔽（マスキング）の手法に触れ ておこう。普通のように下地面のすぐ前に適当な遮蔽板 を置くことにしても非常にこまかい尺度でこれを要求さ れる例として、拡散型高周波トランジスター (Mesa)の 場合エミッターAl, ベース電極 $\mathrm{Au}$ の矩形膜 $(0.001 \times$ 0.006in.) を平行に 0.0005 in 離して Ge n一型層の上に 蒸着しなければならないとき、これを第13図(a)のよう に一つのマスクと 2 本の平行フイラメントによって行っ ている(75)。この際の残留ガスによる散乱の式をGnaedinger が導いているが、実際との比較は充分でない。 超電導膜の蒸着の際のマスキングに関連する縁の問題に ついては後で述べる。

マスキングの精度と再現性を要求される場合写真的手 法がよく用いられている。400 lines / in.のグレーテイン

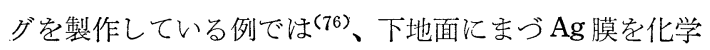
メッキして重クロム酸感光乳剤を塗布し、白黒ネガで密 着露光、現像すると、露光しない部分は温水で洗い流せ るのでその際露出した $\mathrm{Ag}$ 膜を酸で除き、更に残りの乳 剂を拭きとると下地面の $\mathrm{Ag}$ 膜マスキングが完了する。こ れに $\mathrm{SiO}$ 膜或いは $\mathrm{Cr}-\mathrm{Al}$ の 2 層膜を蒸着してこすれば、 これらの膜が残って透過或いは反射型グレーテイングが 光られるという。また、ジグザグ模様の抵抗薄膜の蒸着
には Kodak の Photoresist。と称する感光剂を用いてマ スキングが行われており（第13図(b)）、この場合も露光 されなかった部分が除かれてマスクとなり、蒸着後有機 溶剤でPhotoresist 及びこの上の膜が除か礼る(10)’(11)。

\section{5. 蒸着膜の構造}

蒸発飛来分子が下地面に凝結して膜を形成する機構と 膜の構造は電子顛微鏡、電子回折などによる観察、或い 注光学的、電気的、磁気的特性の測定など種々の手段に よって研究されつつ市り、それらの結果は今日ではかな りよく整理されてきていると思われる ${ }^{(1) \times(41) \times(66) 。 こ れ ~}$ らの詳細な説明はとても筆者の及ぶところではないの で、そ礼は各専門分野の方々の解説に称任せして、ここ では蒸着膜の応用に当って心得ておくべき常識程度のこ と簡単にまとめておきたいと思う。

蒸発源から飛来した分子は下地面に到達してから或時 間の間この面上で気体分子のように運動し、その間に再 蒸発するものるあるが、他の到達分子と衝突して "対" をつくるものもあると仮定すれば、"対”の平均滞在時間 は1分子の久の場合に比べて長くなり、更に他分子を捉 えればそれだけ長くなり、このような分子の集りが下地 面上を移動して、やがてェネルギーの訄失と共に下地面 上に固着する(Frenkel の理論)。従って、膜が蒸着され るためには少くとも最初の"対”它つくるに必要な単位 時間当りの到達分子数 $\nu_{e}$ があり、これをこの理論の式 で表すと

$$
\nu e \propto\left\{\exp (u+\Delta u) / k T^{\prime}\right\}^{-1}
$$

となる。ここで、いは飛来分子の下地面えの吸着の土ネ ルギー、、uは "対”の結合エネルギー、 $k$ はボルッマ ン定数、 $T$ は下地面の絶対温度を表す ${ }^{(1)}$ 。

このように最初の"対” の発生法蒸着 速 度、下地面温 度、下地面の種類などにより異るわけであるが、このこ とに関する一例として、最近 Preuss は増感法と称する 手法で蒸発源の写真をとっている(40)。Zn などの低融点 金属が室温程度で蒸着し難い下地面でも、予め $\mathrm{Ag}$ など の高融点金属をごく微量蒸着しておけ抒、これを中心 して Zn の凝結が行われ、膜が形成されるので、コン デンサー・ペーパーえの $\mathrm{Zn}$ 連続蒸着の際に既に応用さ れている(4)。Preuss はこのことから着想して、酶酸ブ チル・セルローズを塗ったコンデンサー・ペーパーに $\mathrm{Ag}, \mathrm{Au}$ など (増感剤) のピンホール蒸着を行い(平 均厚さ $10^{-2} \AA$ )、こ机に $\mathrm{Zn}$ 或いは $\mathrm{Cd}$ の膜を蒸着し て (現像) 蒸発源のピンホール写真をとった。この際は じめの増感剤が厚過ぎると思われる部分では反転現像に 似た現象もみられるという。第14図は Preuss の手法に 


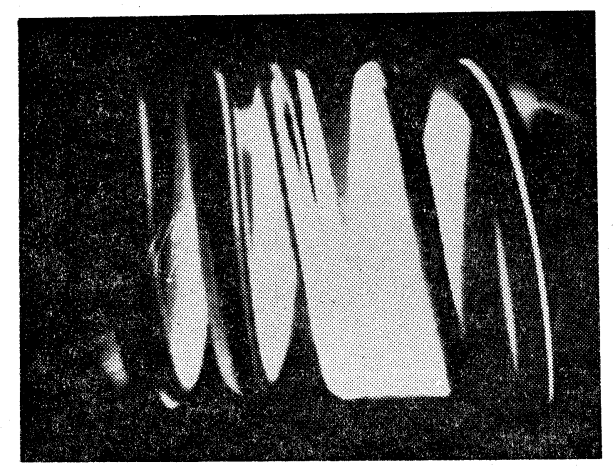

第14図 蒸発源のピンホール写真。フイラメント・ コイル $0.5 \mathrm{~mm} \phi \mathrm{W}$ 線、増感剂 $\mathrm{Ag} 10 \mathrm{mg}$, 蒸発距離 $1.5 \mathrm{~cm}$, ピンホール $40 \mu \phi$, 倍率 $\times 2$ 。

従って試夕たピンホール写真で、増感剤に $\mathrm{Ag}$, 下地面に は $35 \mathrm{~mm}$ フイルムのベースを用いて、Cd現像したもの である。

さて、蒸着分子の集りは他の到達分子を捉えて次第に 大きくなるが、或る大きさになると安定な規則性をもつ ようになり（結晶核の発生）、蒸着の続行によって結晶 粒の面積が桩がり、それだけ数は減少して下地面を殆え ぞ蔽い尽し、やがて厚さの方向に成長することになる。 この初期の微晶粒の成長の模様は電子顕微鏡、電子回折 などによって研究されているが、一般には下地面の小さ な凹凸や規則性の有無、被蒸発物質との結晶型や格子定 数の差異などとの間の明確な関係はまだ見当らない。し かし、大概下地面に平行した規則性を示すようである。 また、このようにして膜が形成されるので、膜は種々の 欠陷を内蔵した微晶粒の充填した構造で、残留ガスの 吸着による空孔、結晶の不整、或いは忘力などのため に物理的性質は塊状の值とは幾分異るのが普通であ $3^{(41) \cdot(42)}$ 。

薄膜の応力は下地面の変形から実測されるが、その原 因は、蒸着中高温の膜面が室温まで泠却する際の取縮に よる(従って、普通の下地面の場合殆えど張力で、その 大きさはヤング率と収縮率の積の程度）、或いは、蒸着 中に生じた格子欠陥の拡散消滅による体積の収縮にもと づくなどの説明がある(44)。膜が非常に厚くなると遂に は自壞し、表面からの大部分が剝離するのは内部応力に よる。

蒸着速度も膜の粒子の大きさにかなり影響する。飛来 分子が多いと、下地面上における移動範囲の小さいうち 飞結晶核が容易に形成されるので、これの数が増え、従っ て平均の厚さの薄い間に既に一様な充槙が行われる ${ }^{(45) 。}$ このことは、一例をあげれば、 $\mathrm{Ag}$ 半透膜の光の吸収の
低減の意味で実際にも応用されている。

下地面温度が膜の構造や性質に大きな影響を及ぼすこ とは度々触れたが、一般に下地面温度が高くなると結晶 粒が大きくなる。近時、蒸着機構の解明、半導体薄膜の 応用などの目的から単結晶薄膜の蒸着が試みられつつあ るが、この場合、膜との境界面でのエネルギーを低くす る意味から膜の物質に近い格子定数の值をもつ下地面 で、少くとも数分子程度の階段しかない滑かな表面它用 いて、（䢃開の階段に蒸着分子が捉えられ易いことが観 察されている) ${ }^{(56)}$ 、適当に下地面温度を高めて苲着を行 うのが普通である( ${ }^{(42)}$ 。

蒸着分子の入射角が大きいときは、はじめの微晶粒 は普通に形成されてもその成長が次第に蒸発源方向に傾 いてくる (自己蔭影の効果)。そのため $\mathrm{MgF}_{2}$ 膜、 $\mathrm{Al}$ 膜 では入射角〜 $40^{\circ}$ 以上になると光の散乱も著るしく、機 械的にも弱くなることが実用的な意味から指摘されてい たが(46)、半導体薄膜の光起電力の現象、磁性薄膜の磁 気異方性の現象などが蒸着角に関する問題として近時注 目されている。

CdTe $150 \sim 200^{\circ} \mathrm{C}$ のパイレックス・ガラス板に入 射角数十度、蒸着速度〜 $1000 \AA / \mathrm{min}$ で蒸着した厚さ〜 $1 \mu$ の膜は、厚さと同程度の結晶粒を充埧した構造で、これ に白色光を当てて $200 \mathrm{~V} / \mathrm{cm}$ (室温) $7000 \mathrm{~V} / \mathrm{cm}$ (液体窒 素温度) の光起電力が観測されるととを Goldstein 等が 示した(第15図) ${ }^{(47)}$ 。これは上記の自己蔭影効果によって 相隣る結晶粒の接触面で $p$ 一 $n$ 接合を形成して、個々の 接合面では〜0.1Vの起電力しか生じないが、これの多 数が直列に並えでいるためにこのような高い電圧が生ず るのであろうという解勫が一応なされているが(47)、光 起電圧の極性、感度最大の蒸着角などは下地面の種類、 温度などによって相違があり、これらについて更に詳し い研究が行われている(原留) ${ }^{(48)}$ 。

同じ現象は Ge膜の場合にも顕著で、特に膜を一度空 気又は酸素に懪すことによって光起電力は著るしく増大 し、入射角 $45 \sim 60^{\circ}$ 、膜厚 $200 \AA$ で $1000 \mathrm{~V} / \mathrm{cm}$ も得ら

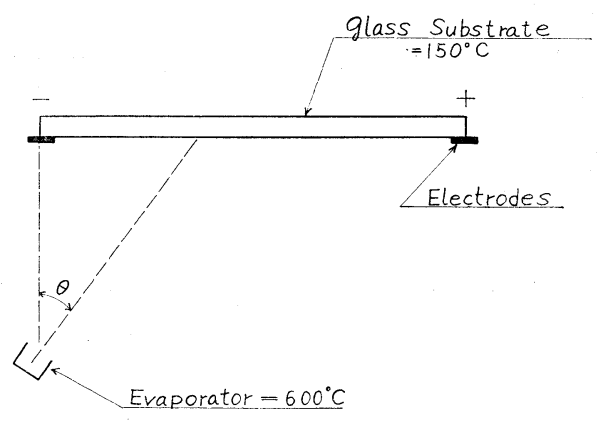

第15図 $\mathrm{CdTe}$ 蒸着膜の蒸着方向々光起電力の極性 (Goldstein \& Pensak)。 
れ、またこの $\mathrm{Ge}$ 膜を直交ニコルの間に挿入してみると 蒸着方向に垂直の方向附近で左旋光性が認められるので 膜の結晶方位と入射角との間に関係のあることなどを中 井が報告している(48)。

これらの例でもみられるように、膜の光電特性は極め て構造に敏感で、それらの充分な説明はまだなされてい ないようであるが、而も個々の光電薄膜の製作技術は確 立され、数十年来実用に供されている(54)。これらにつ いては本稿では煩雑にもなるので触れないことにした。

さて、磁性薄膜における蒸着角の影響は、磁場をかけ ておかなくても繁気の入射方向と直角の方向に磁化容易 方向を生ずる現象としてみられる。また、垂直に蒸着し ても容易方向の摇らぎが認められ、 $\mathrm{Al}, \mathrm{Au} と ゙$ 非磁性の 薄膜を斜に蒸着してからこれに $\mathrm{Fe}$ - $\mathrm{Ni}$ 膜を重直に蒸着 しても同様に磁気異方性を生ずる(49)。下地面の清浄 度(第 1 表参照) 及び種類、真空度、下地温度、膜の組成 $(17 \mathrm{Fe}-83 \mathrm{Ni}$ 附近の組成のものが応力の影響が最も少 い)などが悉く膜の性質に影響を与えるので、このよう な現象を明らかに説明することはまだできないようであ るが、前に述べた半導体薄膜の場合と同じように、微晶 粒の成長過程において自己蔭影が行われることが原因の 一つに考えられている(8)。

\section{6. 混合物の蒸着、膜の硬さ}

混合物、固溶体などの蒸着技術も近時重要視されて来 たが、これらは (a)単一蒸発源からの蒸発、(b) 異る蒸発 源に成分を分けて同時蒸発、(c) 異る蒸発源からの交互 蒸着とその熱処理などの手段によって行われている(52)。

(a)の方法は合金膜の蒸着によく行われているが、蒸気 の成分ともとの合金の成分の間に明確な関係は見出せな いので、一般には予備実験によって確めておかねばなら ない。2 成分系の合金の場合は溶液の蒸気圧に関する Rault の法則によって或る程度予測できるとされている が(3)・(14)、例えば、アルミナ・ルツボの傍熱加熱で 16.6 $\mathrm{Fe}$ - $83.4 \mathrm{Ni}$ を $1600^{\circ} \mathrm{C}$ で蒸発すれ汪 $38 \mathrm{Fe}-62 \mathrm{Ni}$ 膜が 予想されるのが、実際には $18.5 \mathrm{Fe}-81.5 \mathrm{Ni}$ (バラッキ は土0.5 程度）の膜が蒸着されることを Blois は報告し ている(7)。磁性薄膜の蒸着にはこの方法がよく用いられ ている(8)・(9)。とのような面倒丧避けるため少量づつを フラッシユする方法があり、第 1 節の $\mathrm{Cr}$ - $\mathrm{Si}$ 抵抗薄膜 はこれ行っている(13)。また細い線を蒸発源に送り込 む方法も利用され (4)、電子加熱蒸発にこれが行われてい ることは先に述べた。

(b)の方法の例として、金属シートえのガラス薄膜の蒸 着(14)、InAs 或いは InSbのいわゆる III $-\mathrm{V}$ 化合物半導
体の蒸着に関する Günther等の例が見られる(50)。その 場合、成分単体の蒸気圧曲線を用いて所望の混合比を得 る方法をとっているが、再蒸発など実際の条件を検討し なければ化学量論的な化合物としては得られない。ま た、最近 Campbell 等が $\mathrm{ZnS}$ - LiF 混合膜の蒸着を行っ た結果を報告しているが(43)、混合膜の厚さは各成分膜 を別々に繁発して重ねたとして期待される厚さに比べて かなり薄いという。そこで LiF膜、或いは $\mathrm{ZnS}$ 膜の上に 他方の膜を蒸着し、その際適当に遮蔽したガラス面に反 射してくる分子による膜の愿さを測って、 $\mathrm{ZnS}$ 膜上に LiF 蒸着する際の凝結係数は殆えど 1 に近いが、逆の 組合せでは $\mathrm{ZnS}$ の凝結係数は膜の平均厚さが $0.5 \rightarrow 5 \AA$ と増加する間に $0.2 \rightarrow 0.95$ 程度の変化をすることを認め ている。これは $\mathrm{ZnS}$ 膜の凝結核発生の機 構と関連した 現像で、結局、上記混合膜の膜厚の減少は $\mathrm{ZnS}$ の再蒸発 に起因すると説明される。

(c)の方法は各成分の蒸発総量をきめておけば、えられ る合金膜の組成が定まり、而も合金の融点より遙に低い 温度で拡散し合わすことができるので都合がよい(51)。 しかし、金属膜相互の拡散の現象は非常に複雑で ${ }^{(52)}$ 、 処理温度もそれに左右される。次にここで、横道にそれ て拡散による経時効果の例を簡単に述べよう。

ガラス面に Cr膜を蒸着してから Al 膜を蒸着すると膜 が著るしく強くなるので従来 $\mathrm{Al}$ 表面鏡に応用されてお り、前に反射型グレーテイングの例でも触れた。このよ うな現象は他の下層膜との組合せの場合にもみられ、第 16図は Weaver \& Hill がそれらの空気中での経時変化 を測った結果から数例を描いたものである(53)。膜の硬 さはクロム鋼球で膜面を引搔き、溝の底で完全な剝離の 認められたときの最少荷重で表している。下層が Cr の 場合は拡散によって何れの結晶構造とも異る中間層を生 じ、このような格子の不整による硬化が起るものと考え られ、Coの場合は合金が容易に作られて、その際もと の膜の構造が完全に破壞されて再配列するので下地面と の附着が悪くなり、 $\mathrm{Pb}$ との組合せでは極めて拡散し難 いので下の層より僅に強くなる程度に止まると説明され， る(52)。また、下層の $\mathrm{Cr}$ 膜が 300〜400Å の厚さになる と硬さの值が飽和し、これは $\mathrm{Cr}$ 膜の微粒子がほぼ一様 に下地面を蔽うときである(53)。

また、ここで蒸着膜の硬さ試験について一言しよう。 膜の実用的見地から膜の硬さの数量的表示索必要とする 場合が多く、彷来いくつかの方法が試みられてはいる が、それらの值の意味は明らかでない(50)。Benjamin \& Weaver は(55)、上記の引搔き試験法でえられる荷重 $W$

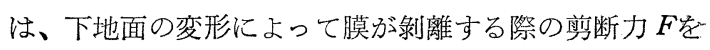




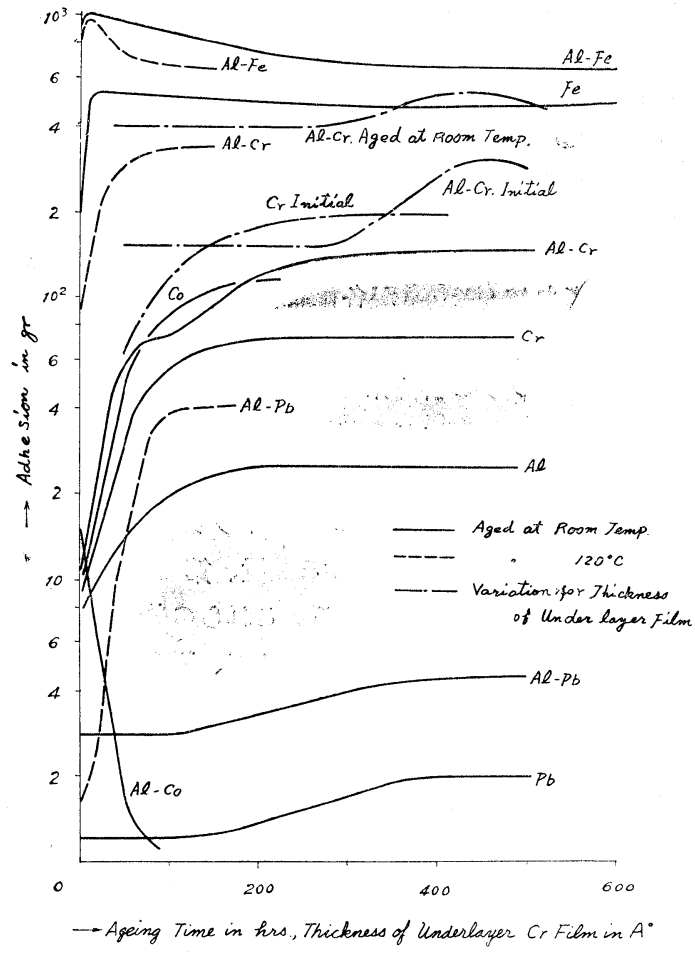

第16図 種々のアンダー・コーテイング金属膜を用 いたときの $\mathrm{Al}$ 膜の硬さの経時変化。

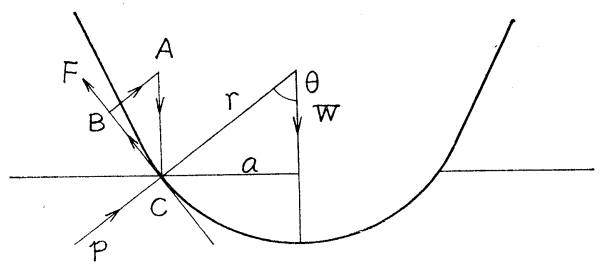

第17図引掻き試験の際の剪断力 (Benjamin \& Weaver)。

与えるものと考えて、第17図の関係から

$$
F=a\left(r^{2}-a^{2}\right)^{-1 / 2}-p, a=(W / \pi p)^{1 / 2} \cdots \cdots(5)
$$

を導き、このようにしてえられたガラス上の $\mathrm{Ag}$ 膜の值 は $F=3.1 \times 10^{-9}$ dynes $/ \mathrm{cm}^{2}$ であった。ここで、 $a$ は塑 性変形した下地と半径 $r$ の鋼球との接触円の半径、 $p$ は 塑性変形した下地物質内の圧力を表わす。彼等は更に、ポ テンシャルの高さが付着力の尺度であり、剪断力は境界 面に护る分子相互の滑りと考えて、理論的に求めた凝 結のエネルギーから計算した剪断力と上記の結果を比較 してかなりよく一致することを示している。しかし、こ の理論的に求めた凝結のエネルギー (4)で実測した $\nu, T$ の值を入れて計算した $\Delta u$ の值は、
$u>\Delta u$ となり、これは(4)式の仮定と矛盾するなどまだあ いまいな点もあるが、膜の硬さ試験の解釈に野心的な試 みを行ったものとして注目に值しよう。

\section{7. 超高真空蒸着装置}

高真空における蒸着の際に、ゲッタ一効果による真空 度の上昇は我々のよく経験するところで、またこの領域 での残溜気体圧力が膜の構造、特性などに大きな影響を 及ぼすことが多くの場合に観察されている。実際、 10-5 Torrで下地面に衝突する残溜気体分子の数は〜10 $16 /$ $\mathrm{cm}^{2} \cdot \mathrm{sec}$ と推定されて、これは例えば $\mathrm{Ag}$ 膜の蒸着速度

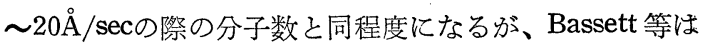
マイカ或いは $\mathrm{NaCl}$ 単結晶䢃開面上に蒸着した $\mathrm{Ag}$ 膜で $10^{10} \sim 10^{11} / \mathrm{cm}^{2}$ の転位を観察している(56)。また、Glesons 等は ${ }^{(57)} 、 \mathrm{Fe}$ - Ni 磁性薄膜它真空炉中で焼いて放出ガス の分析を行い、膜はもとの塊状金属に比べて $10^{3} \sim 10^{4}$ 倍 のガスを放出し、膜の分子数 $m_{g}$ と放出ガス分子数 $m_{a}$ の割合は蒸着時間 $2 \sim 15 \mathrm{~min}$ に従って $m_{g} / m_{a}=$ (98

第 2表 各種蒸着装置の残留ガス( aswell)

\begin{tabular}{|c|c|c|c|c|}
\hline \multirow{2}{*}{ 気 体 } & \multicolumn{4}{|c|}{ 圧 力 (Torr) } \\
\hline & I & II & III & IV \\
\hline $\mathrm{H}_{2}$ & $4 \cdot 10^{-7}$ & $2 \cdot 10^{-7}$ & $4 \cdot 10^{-8}$ & $2 \cdot 10^{-9}$ \\
\hline $\mathrm{O}_{2}$ & $5 \cdot 10^{-7}$ & $4 \cdot 10^{-8}$ & $5 \cdot 10^{-10}$ & $<10^{-10}$ \\
\hline A & $3 \cdot 10^{-8}$ & $5 \cdot 10^{-9}$ & $8 \cdot 10^{-10}$ & $<10^{-10}$ \\
\hline $\mathrm{N}_{2}$ & $1 \cdot 10^{-6}$ & $2 \cdot 10^{-7}$ & $1 \cdot 10^{-8}$ & \multirow{2}{*}{$8 \cdot 10^{-10}$} \\
\hline $\mathrm{CO}$ & $9 \cdot 10^{-7}$ & $5 \cdot 10^{-8}$ & $2 \cdot 10^{-8}$ & \\
\hline $\mathrm{CO}_{2}$ & $6 \cdot 10^{-8}$ & $3 \cdot 10_{-}{ }^{9}$ & $2 \cdot 10^{-9}$ & $<10^{-10}$ \\
\hline $\mathrm{H}_{2} \mathrm{O}$ & $5 \cdot 10^{-6}$ & $5 \cdot 10^{-7}$ & $7 \cdot 10^{-8}$ & $<10^{-10}$ \\
\hline $\mathrm{CH}_{4}$ & $1 \cdot 10^{-8}$ & $<10^{-10}$ & $7 \cdot 10^{-9}$ & $<5 \cdot 10^{-11}$ \\
\hline $\mathrm{C}_{3} \mathrm{H}_{8}$ & $2 \cdot 10^{-8}$ & $2 \cdot 10^{-9}$ & $2 \cdot 10^{-9}$ & $<5 \cdot 10^{-11}$ \\
\hline $\mathrm{C}_{4} \mathrm{H}_{10}$ & $6 \cdot 10^{-9}$ & $1 \cdot 10^{-9}$ & $1 \cdot 10^{-9}$ & $<5 \cdot 10^{-11}$ \\
\hline $\mathrm{C}_{5} \mathrm{H}_{12}$ & $2 \cdot 10^{-9}$ & $4 \cdot 10^{-10}$ & $5 \cdot 10^{-10}$ & $<5 \cdot 10^{-11}$ \\
\hline$\sum \mathrm{P}_{\mathrm{j}}$ & $8 \cdot 10^{-6}$ & $1 \cdot 10^{-6}$ & $2 \cdot 10^{-7}$ & $3 \cdot 10^{-9}$ \\
\hline $\mathrm{P}^{*}$ & $8 \cdot 10^{-6}$ & $2 \cdot 10^{-6}$ & $6 \cdot 10^{-7}$ & $6 \cdot 10^{-9}$ \\
\hline
\end{tabular}

* 較正してない電離真空計の読み。

I 普通の蒸着装置、油拡散ポンプ排気。

II 加熱ヒーター、Meissner トラップを装 供した普 通の蒸着装置。

III Meissnerトラップを装備した特殊蒸着装置、Vac Ion ポンプ排気。

N 超高真空蒸着装置、Vac Ion ポンプ排気。 


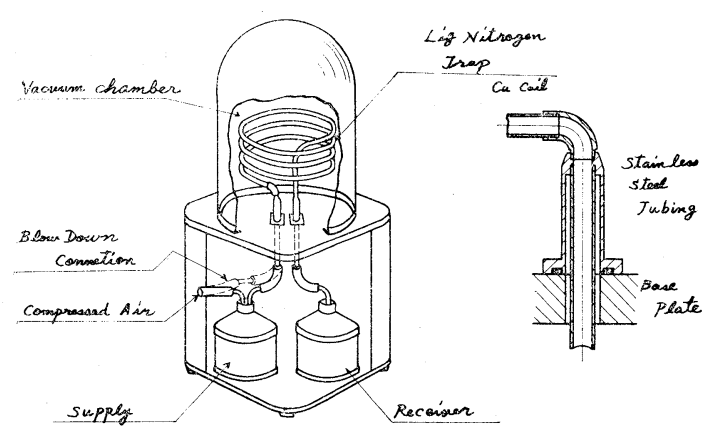

第18図 Meissner トラップ(Meissner)

第3表 器壁からの比ガス流入量 (Alpert)

真空系の種類がスの種類 器壁材料 窒温での比流入速

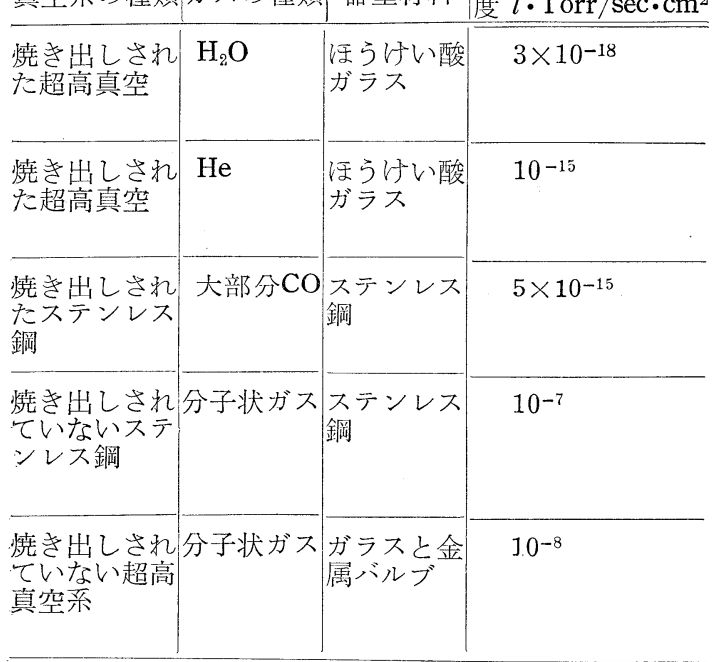

〜2.6) $\times 10^{-3}$ にもなることを示している。そして放出が 大の殆えどが $\mathrm{H}_{2}$ と CO で、こ秃らは拡散ポンプ油に由 来するととを結論している。

また、我々のよく用いている蒸着装置はどのような残 溜ガス組成をもっており、これを改良すればどのような 組成になるかという点についての代表的な例を第 2 表に 示とう。これは Caswell が各種蒸着装置に質量分析管を 取りつけて観測したもので(59)、第 I 列は油拡散ポンプ 液体空素トラップの排気系でゴムのシールを用いたごく 普通の装置、第II列はこの装置で内部加熱可能にして Meissner トラップを用いたもの、第吕列は全金属製で Vitonをシールに用い、Meissner トラップを装備して 大型 VacIonポンプで排気する装置、第 $\mathrm{N}$ 列は後の第 20図に示す超高真空装置である。これらの装置の蒸着中 のガス成分の変化も論議されているが、詳細は割愛す る。なお、Meissnerトラップというのは第18図に示す ように銅管コイルに液体窒素を入れたもので、蒸着室内 の油蒸気など至凝結してしまうためのもので、最近は広 く使用されている(58)。

さて、これらの事実から、残溜ガスの影響の非常に少 くなる筈のいわゆる超高真空での蒸着に当然期待が寄せ られるのであるが、Alpert に始まる超高真空技術の素晴 らしい発展によって ${ }^{(6 i)} 、$ 取りはづし可能なかなり大き い超高真空装置の組立て、排気もできるようになり、こ の数年来超高真空における蒸着の例が次第に多く見られ るようになった。

空気中の水分を吸着した器壁を室温のま委で排気して

第 4 表 各種超高真空蒸着装置

\begin{tabular}{|c|c|c|c|c|c|}
\hline No. & $I^{*}$ & II $^{(61)}$ & IIII ${ }^{(62)}$ & $\mathrm{IV}^{(63)}$ & $V^{(59)}$ \\
\hline 主要構成材料 & ほうけい酸ガラス & ほうけい酸ガラス & ステンレス 鋼 & ステンレス 鋼 & ステンレス鋼 \\
\hline 排 気 采 & $\mathrm{DP}-\mathrm{NT}$ & $\mathrm{DP}-\mathrm{NT}-\mathrm{CT}$ & $\mathrm{DP}-\mathrm{NT}$ & $\begin{array}{l}\mathrm{DP}-\mathrm{NT} \\
\text { (Vac Ion ポンプ可 } \\
\text { 能) }\end{array}$ & $\begin{array}{l}\text { 流水ポンプークライ } \\
\text { オポンプ, Vac Ion } \\
\text { ポンプ }\end{array}$ \\
\hline バ ル ブ & マグネット駆動 & $\mathrm{Ga}-\mathrm{In}-\mathrm{Sn}$ 合金 & 無 し & （金属、可能） & 金 属 \\
\hline $\begin{array}{c}\text { 焼さ出し温度 } \\
\left({ }^{\circ} \mathrm{C}\right)\end{array}$ & 350 & 350 & 500 & 450 & 430 \\
\hline 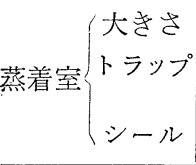 & $\begin{array}{c}4^{\prime \prime} \phi \\
- \\
\text { Ga-In-Zn合金 }\end{array}$ & $\begin{array}{c}67 \mathrm{~mm} \phi \\
\mathrm{He} \text { 指状トラップ } \\
\text { 金属ナイフ・エッジ }\end{array}$ & $\begin{array}{c}12^{\prime \prime} \phi \times 18^{\prime \prime} \text { (二重壁) } \\
\text { 一 } \\
\mathrm{Cu} \text { ナフ・エッジ }\end{array}$ & $\begin{array}{l}10 l \text { (二重壁） } \\
\text { Meissnerトラップ } \\
\text { 金属ガスケット }\end{array}$ & 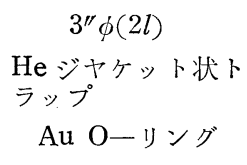 \\
\hline $\begin{array}{l}\text { 王力 } \\
\text { (Torr) }\end{array}$ & $\begin{array}{c}10^{-8} \\
-\end{array}$ & $\begin{array}{c}10^{-9} \sim 10^{-10} \\
10^{-8}\end{array}$ & $\begin{array}{c}10^{-9} \\
-\end{array}$ & $\begin{array}{l}10^{-9} \sim 10^{-10} \\
10^{-8} \sim 10^{-9}\end{array}$ & $\begin{array}{c}10^{-10} \sim 10^{-11} \\
10^{-10}\end{array}$ \\
\hline $\begin{array}{l}\text { 蒸 発 源 } \\
\text { 被蒸発物 }\end{array}$ & $\begin{array}{c}\text { 電子加熱 } \\
\mathrm{Fe}-\mathrm{Ni} \text { 合金 }\end{array}$ & $\begin{array}{c}\text { 金属フイラメント } \\
\mathrm{Fe}\end{array}$ & - & $\begin{array}{c}\mathrm{W} \text { フイラメント } \\
\mathrm{Ag}, \mathrm{Al}, \mathrm{Au}\end{array}$ & $\begin{array}{c}\mathrm{Ta} \text { ボート } \\
\mathrm{Sn}\end{array}$ \\
\hline
\end{tabular}

* D. M. Hart ${ }^{(35)}$ ，DP : 油拡散ポンプ， NT : 液体窒素トラップ， CT : 活性炭トラップ 


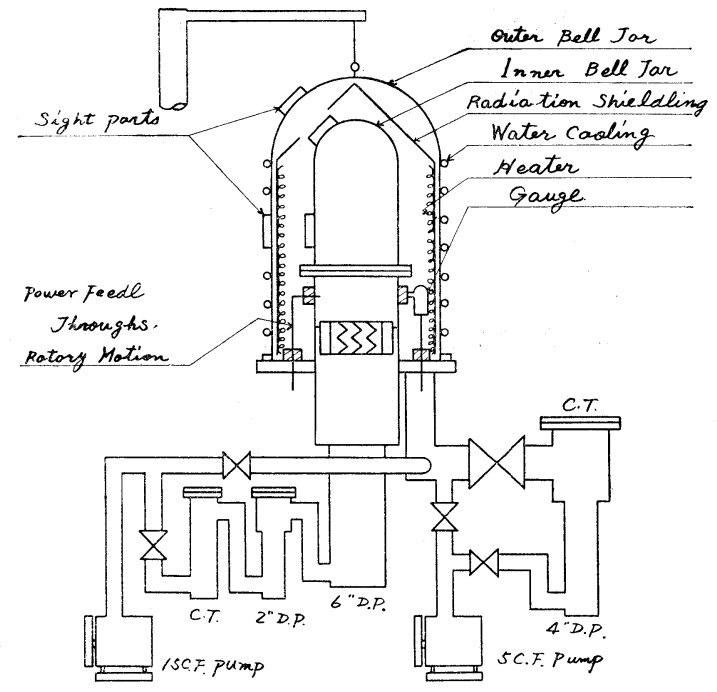

第19図 超高真空蒸着装置 (Rivera \& Riche)

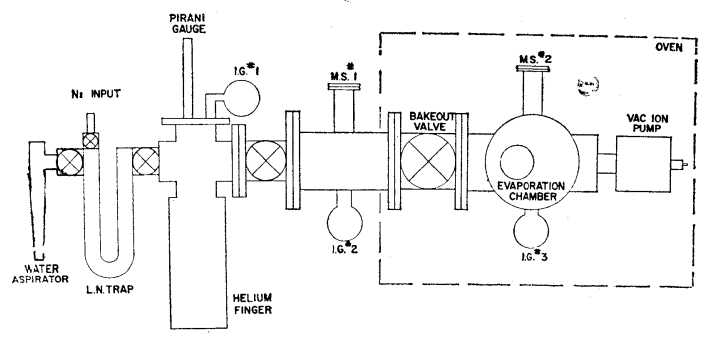

第20図 超高真空蒸着装置 (Caswell)。

除去するととは実際上不可能で、よく知られているょう に、超高真空装置では焼き出し排気の操作が不可欠であ る。第了表はこの燒き出しの効果を示す(Alpert) ${ }^{(60)}$ 。ま た、蒸着装置の場合は脱着可能な蒸着室の構造を必要々 し、被蒸発物からのガス放出があるので、いわゆるダイ ナミックな超高真空系となる。第 4 表に代表的な数例を まとめてみた。第列 (第19図)、第 IV 列注 2 重容器に して、外側容器内定〜10-5 Torr 飞排気する方法で、こ れによって金属ガスケットその他の漏り及びそのテスト を普通の高真空なみに报うという考光にもとづいてい

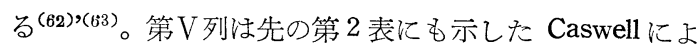
る装置で、その配列は第20図に示す。また最近の Hollandの結果も参照されたい(7th Vac. Tech. Trans., 168)。

さて、Caswell はこのような超高真空装置を用いて $\mathrm{Sn}$ 超電導膜を蒸着し (下地面は室温)、特に残溜 $\mathrm{O}_{2}$ の 影響をしらべている(64)。超電導薄膜の゙電流密度は膜の 縁で最も高く、従って正常電尊えの遷移は僅少な電流值 で既に縁から始るので、超電導を破るに必要な磁場と残 溜抵抗の関係は多少傾斜特性を示し、楔形断面の膜では

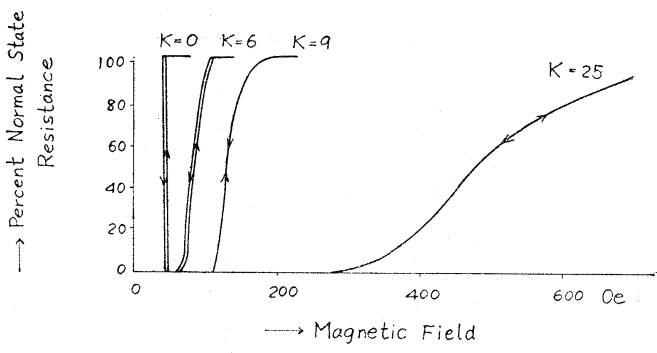

第21図 Sn 超電導膜の磁場一残溜抵抗特性, $T / T_{\mathrm{C}}$. $=0.946$ (Caswell). $K$ は下地面に当る $\mathrm{O}_{2}$ 分子 の

$\mathrm{Sn}$ 分子に対省る比。

この傾斜が顕著になる(16)。いまの場合、 $\mathrm{O}_{2}$ が下地面に 吸着されている状態では $\mathrm{Sn}$ 分子の沿面移動が少く、マ スキングの蔭の部分は楔型に膜厚が減少し，上記特性が 著るしく傾斜する(第21図)。これに反して、〜10-3Torr での蒸着では $\mathrm{Sn}$ 分子の移動範囲が大きいので、縁は大 粒に成長したSn 粒子が殆えど不連続に散在し（顕微鏡 観察）、矩形断面をもつ膜と同じょうな急激な磁場一残 留抵抗特性分現われるのである之説明される(64)。

また、Mayer 等は焰で平滑にしたガラス板に〜10-9 'Torr で K, Csなどアルカリ金属を蒸着し、その際下地面 以液体空素温度に冷却して蒸着分子の沿面移動定防ぎ、 このようにしてえられた膜の電気抵抗などを測定した。 そして、3〜4分子層の厚さから既に金属的な導電性の認 められること、電気抵抗測定值の再現性が高いこと、その 抵抗值は膜厚数 $+\AA$ 程度から電子の平均自由行程の理論 による值とよく一致することなどを示している(1),(65)。

これら一、二の結果でも見られるように（従来の綜合 報告も参照されたい( $(60))$ 、我々の予想以上の結果がえ られつつあり、超高真空に括ける蒸着は今後更に数々の 好結果を招来するものと期待される。

\section{8. 膜 厚 の 制 御}

膜の反射又は透過率を測りながら蒸着することによっ て所望の厚さの膜を蒸着する方法は工場においても次第 に普及している。薄い金属膜、簡単な構成の干涉薄膜な ぞの場合はガラス・フイルター、或いは低次の銀干渉フ イルターを通った光について光量変化を測れば充分であ $\zeta^{(4) \cdot(67)}$ 。

いわゆる $\lambda / 4$ 交互層の波数特性注中心波長 $\lambda$ 波数 $1 / \lambda$ の両側で対称な曲線になる。従って入の両側に余 り大きくない、等しい波数間隔の位 置に 観測波長をき め、はじめ膜の蒸着されてないときの光量差の指示が零 になるようにして执いて (零調節)、順次メーター指示 が零になる毎に蒸着を止めれば $\lambda / 4$ 膜が重视られる。こ 

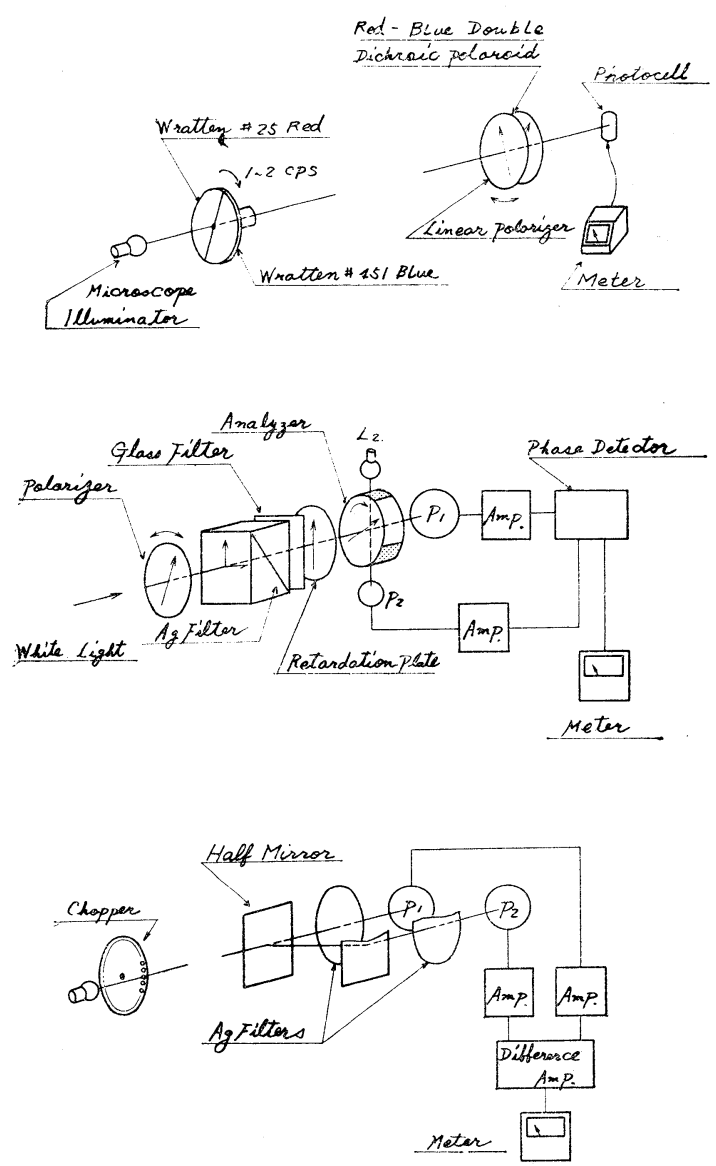

第22図引 2 2色測光による干渉薄膜の蒸着監視装置光学系。

のような蒸着監視装置として、2 枚のゼラチン・フイル ターを用いて 2 枚の 2 色性ポーラロイドで零調節を行う もの（第22図(a)） ${ }^{(68) 、 1 ~}$ 枚の銀干渉フイルターを斜入 射で用いて波長位置の異る三つの偏光成分について、2 枚のポーラロイドで零調節するもの (同図(b)) (69)、2 枚の銀干渉フイルター、 2 本の光電管を用いて増幅器で 電気的に零調節するもの (同図(c)) (32) (70)、なぞが報 告されており、何れも蒸着の現場で使用されているよう である。勿論これらの装置で一つの波長帯のみに技ける 測定もできる。

しかし、このような 2 色測光の方法で多層狭帯域フイ ルターの制御を行うにはスペーサー層の前後附近で下地 面を新たに取り替えるばならず、このようにして行った 筆者の例では土 $2 / 65$ 程度の再現性であった ${ }^{(70)}$ 。との意 味で、分光器を用いて、層数が增しても最後迄光量変化 に規則性のある入のごく近傍のみで波長掃引する方法が 遙に再現性がよく、 る(71)。これらの詳細は割 愛する。また、交互多層膜の

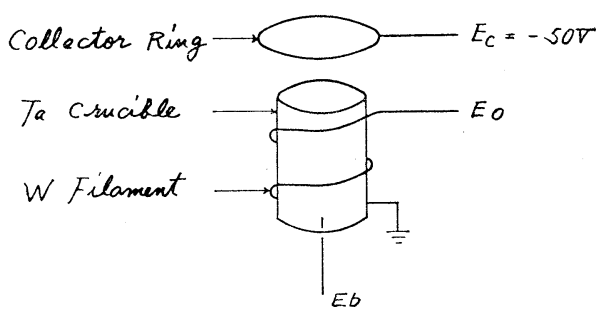

第23図 イオン電流監視型蒸発源 (Reames)。

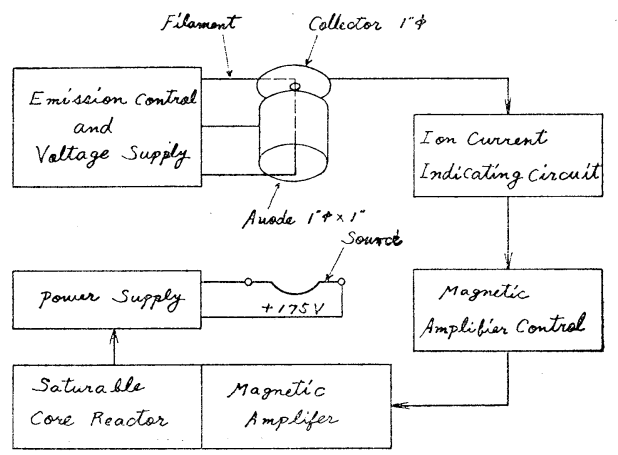

第24図 電離真空計型蒸発速度制御装置

(Fied \& Perkins)。

各層が $\lambda / 4$ の整数倍でない場合は以上の手順て簡単に制 御することはできないので、監視面、観測波長の取り替 えなどを行わねばならない。

金属膜の厚さは電気抵抗を測定していて制御すること がでさ、抵抗薄膜、磁性薄膜などの場合よく行われてお り、測光の方法と併用する例も多い。均質な金属塊を次 第に薄くしたとしても、電子の運動は膜面で散乱を受け るようになるので、薄膜の電気抵抗は電子の平均自由行 程と膜厚の項を含む式で表される ${ }^{(1)}{ }^{(65)}$ 。しかし、蒸着 膜の場合には一般に塊状の值から推定した抵抗值よりは 大きく、蒸着条件によって著るしく左右されるのが普通 で、予備実験によって膜厚との関係を第 3 困のように決 めてかから称ばならない。超高真空に和ける蒸着では電 気抵抗による膜厚制御の精度はよくなる箱である(65)。

また、蒸発分子のイオン電流を測る方法が最近よく用 いられ、イオン電流を一定に保ち蒸発時間によって所望 の膜厚が党られる。Mayer 等はアルカリ金属の蒸着の際 に行っており ${ }^{(65)}$ 、第23図はReames が電子加熱蒸発源で $\mathrm{ZnS}$ 系螢光薄膜の蒸着に行っている例である(17)。

また Giedd 等は蒸着槽内に異形の電離 真空計を叔い て入射蒸気のイオン電流を測る方法を考案している（第 24 図 $)^{(72)}$ 。電子電流忹一般の電離真空計におけると同じ ように可飽和リアクターを通じて一定に保ち、同じ原理 を用いてイオン電流の変化を蒸発源ヒーター電流にフイ 
ード・バックして蒸着速度を任意の值に一定に保つよう 工夫してある。真空度が $10^{-8}$ Torr以下のときは残留が スによるイオン電流の補正を要し、また蒸発源からの電 子による影響を除くため蒸発源に正バイアスをかけてい る。蒸着速度とイオン電流注ほぼ膜厚測定の精度内で直 線的であるが $( \pm 4 \%) 、$ 約 $1000 \AA / \mathrm{sec}$ 以上では放電の 崩壊のため使用でさなくなるという。その後 Schwarz は電離真空計に入射する蒸気流をシャッターによって 断続し、イオン電流の交流分のみを測ることによって残 留ガスの影響を除くことを試み、 $\mathrm{Ni}, \mathrm{Cr}, \mathrm{Al}$ について (0.1〜10)Å/sec の析で上記直線性のあるととを示し ている(73)。

最近 Lostis等法、質量 $m$ 、固有周 波数 $f_{0}$ の水晶発振 子に質量 $\Delta m$ の膜がついたために生ずる周波数の減少 $\Delta f=f_{0} \cdot \Delta m / m$ 学観測する方法を提唱した。温度上 昇、膜の見掛けの密度などに問題があるが、予め較正し て $1 \sim 3 \%$ 程度の精度で膜厚制御ができるという(74)。

\section{9. 結 語}

以上、大よそ Holland の成書 ${ }^{(4)}$ 以後の蒸着技術につ いて概観したが、その期待され或いは既に行われつつあ る応用分野は非常に広く、筆者の不勉強のため不充分の 点も多いが、この小稿が多少とも扮役に立つととがあれ ば幸いである。

最後に、本稿について種々論議して頂いた大阪工試岩 田第三部長、当所高柳研究室長、並びに本稿執筆のため の長い時間を許して頂いた当所穂積所長の諸先生に感謝 申し上げる。

\section{[交献]}

(1) H. Mayer : "Physik Dünner Schichten I, II," Wissenshaftliche Verlagsgesellschaft M. B. H. (Stuttgart, 1950 u. 1955)

O. S. Heavens : "Optical Properties of Thin Solid Films," Academic Press (New York, 1955)

(2) 木内："薄膜の光学的研究"、岩波(1954)

M. Auwärter : "Ergebnisse der Hochvakuumtechnik und der Physik dünner Schichten" ; Wissenshaftliche Verlagsgesellschatt M. B. H. (Stuttgart, 1957)

(3) J. Strong: "Modern Physical Laboratory Practice," Blackie (London, 1944)

S. Dushman: "Scientific Foundations of Vacuum Technique," John Wiley (New York, 1949)

(4) L. Holland: "Vacuum Deposition of Thin Films", JohnWiley (New York, 1956)

(5) R. Pohl \& P. Pringsheim : Verh.Deutsch. Phys.
Gesell. 14, 506, 546 (1912)

(6) 〔綜説】藤原 : 応用物理 29,139 (1960)

(7) M. S. Blois : J. Appl. Phys. 26, 975 (1955)

(8) D. O. Smith : ibid 29, 264 (1958); 32, 70S (1961)

R. E. Bittmann: Electronics 32, No. 23, 55(1959)

（9）〔綜説】服部：真空 2, 379 (1959); 飯田：物性 1, 70 (1960); F. B. Humphery et al :5th Vac.

Tech. Trans., 204 (1958)

(10) [綜説 $]$ G. W. A. Dummer: Wireless World 65, 545 (1959)

(11) T.A.Prugh et al : Proc. IRE 47, 882 (1959) S. F. Danko : ibid, 894

(12) R. H. Alderson \& F. Ashworth : Brit. J. Appl. Phys. 8, 205 (1957); G. Siddal \& G. Smith: ibid 10, 35 (1959)

(13) E. H. Layer : 6th Vac. Tech. Trans., 210(1959)

(14) G. Siddall : Vacuum 9, 274 (1959)

(15) C. Feldman : Rev. Sci. Inst. 26, 463 (1955)

(16) V. L. Newhouse \& J. W. Bremer : J. Appl. Phys. 30, $1458(L)(1959)$; [綜説] E. H. Rhoderick :

Brit. J. Appl. Phys. 10, 193(1959); V. L. Newhouse et al:Solid-State Electronics 1, 261 (1950)

(17) J. P. Reames : Rev. Sci. Instr. 30, 834 (N), (1959); 6th Vac. Tech. Trans., 215 (1959); 7th Vac. Tech. Trans. 219 (1960)

(18) L. Holland: Brit. J. Appl. Phys. 9, 410(1958); Advances Vac. Sci. Tech., 753 (1960)

(19) A. E. Ennos : Brit. J. Appl. Phys. 4, 101 (1953) ; 5, 27 (1954)

(20) J. T. Cox \& G. Hass : J.O.S. A. 48, 677 (1958)

(21) G. K. Wehner: Phys. Rev. 108, 35 (1957); S. P. Wolsky : ibid, 1131; [綜説] G. K. Wehner : Advances Electrons and Electronic Phys. 7, 239 (1955)

(22) N. Laegreid, et al:J. Appl. Phys. 30, 374 (1959); 6th Vac. Tech. Trans., 164 (1959); 7th Vac. Tech. Trans., 286 (1960)

(23) G. K. Wehner : J. Appl. Phys. 29, 217 (1958) B. B. Mechel \& R. A. Swalin: ibid 30, 89 (1959) J.A. Dillon \& R. M. Oman : ibid 31, 26(1960)

(24) R. E. Honig : RCA Rev. 18, 195 (1957) 真空技術基礎講座 (16) : 真空 2, 425 (1959)

(25) S. Nielsen: 7th Vac.Tech. Trans., 293 (1960)

(26) Y. Moriya: Adbances Vac. Sci. Tech., 744(1960), L. Holland : Vacuum 6, 161 (1959)

(27) 田畑、岩田：大工試季報 9, 151 (1958)；10, 19 (1959); S. Tabata et al : Vacuum 7 8, 88 (1959)

(28) D. E. Bradley : Brit J. Appl. Phys. 5, 64(1954) 
10, 198 (1959) ; M. D. Blue \& G. C. Danielson : J . Appl.Phys. 28, 583 (1957)

(29) C. E. Drumheller: 7 th Vac. Tech. Trans., (1960)

(30) 浅野 : 真空 3, 19 (1960)

（31）沢木、他：大工試季報 $5,81,211(1954) ； 9,11$

(1958); T. Sawaki: Science of Light 7, 1 (1958)

（32）沢木：大工試報告 No.315 (1960)

(33) G. Hass, et al : J.O.S.A. 48, 324 (1958) ; 49, 116 (1959)

(34) R. Thun \& J. B. Ramsey : 6th Vac. Tech. Trans, 192 (1959)

(35) D. W. Moore: ibid, 181

D. M. Hart:5th Vac. Tech. Trans., 230 (1958)

(36) 永田、他：真空技術 7, 181 (1956) ; 応用物理 27, 459 (1958); M. S. Lucas, et al : Rev. Sci.Inst. 32, 203(N) (1961)

(37) L. Holland \& W. Steckelmacher : Vacuum 2, 346 (1952) ; M. V.Schneider:J.O.S. A. 50, 18 (1960) K. H. Behrndt: 6 th Vac. Tech. Trans., 242(1959)

(38) O.S. Heavens : J.Sci. Instr. 36, 95 (1959)

(39) L. E. Preuss : J. Appl. phys. 24, 1401 (1953); Vakuum Tech. 9, 93, 121, 155 (1960); Advances Vac. Sci. Tech., 114 (1960)

(40) L. E. Preuss : Vacuum 9, 233 (L) (1959); 6th Vac. Tech. Trans., 228 (1959)

(41) 飼沼 : 物性物理学講座 第10巻、 115 , 共立出版 (1959)

(42)【綜説】 D. W. Pashley:Advances Phys. 5, 173 (1956), G.A. Basset, et al: "Structure and Properties of Thin Films", p.11, John Wiley (New York, 1959)

(43) D. S. Campbell \& H. B. Blackburn : 7th Vac. Tech. Trans., 313 (1960)

(44) (綜説) 近藤、木下：応用物理 28, 553 (1959)

(45) H. Levinstein : J.Appl. Phys. 20, 306 (1949) R.S. Senett \& G.D.Scott : J.O.S.A. 40, 203 (1950)

(46) L. Holland : J.O.S.A. 43, 376 (1953) ; 46, 773 (1956)

(47) B. Goldstein \& L. Pensak : J. Appl. Phys. 30, 155 (1959) ; Phys. Rev. 109, 601 (L) (1958)

(48) 原留、他: 第 8 回応物関係連合講演会予稿集、185 (1960) ; 中井 : ibid, 183; H. Kallmann, et al : J.Electro.Chem.Soc. 108, 247 (1961)

(49) M.S. Cohen, etal : J.Appl. Phys. 31, 291S (1960)

(50) W. Hanlein \& K. G. Günther : Advances Vac. Sci. Tech., 727(1960)

(51) R. B. Belser : J.Appl. Phys. 31, 562 (1960)
(52) [綜説】C. Weaver \& R. M.Hill: Advnces Phys. 8, 375 (1959)

(53) C. Weaver \& R. M. Hill : Phil. Mag. 3, 1402 (1958)； 4, 253， 1107 (1959); [綜説] C. Weaver : Advances Vac. Sci. Tech.,734 (1960)

(54) 例党ば [綜説]J.D. McGee : Proc. IRE 104B, 467 (1957)

(55) P. Benjamin \& C. Weaver : Proc. Roy. Soc. A 252, 418 (1959); 254, 163 (1960)

(56) G. A. Bassett \& D. W. Pashley: J. Inst. Metals 4, 449 (1959)

(57) F. R. Glesons, et al : 6th Vac. Tech. Trans, 222 (1959)

(58) C. R. Meissner : Rev. Sci. Inst. 26, 305 (N) (1955) ; 3rd Vac.Tech.Trans., 15 (1956)

(59) H. L. Caswell : I. B. M. Jour. 4, 130 (1960); Rev.Sci.Inst. 30, 1053(N) (1959); 6th Vach.

Tech., Trans. 66 (1959)

(60) [綜説]一宮、織田：応用物理 26, 313 (1957) 織田：真空 1, 82 (1958); 水島：物理学会誌 15, 631 (1960); D. Alpert : Handbuch der Physik XII, 609 (1958); Advauces Vac. Sci.Tech., 31(1960),

(61) K.H. Berndt: 6th Vac. Tech. Trans. , 255(1959)

(62) M. Rivera \& R. LeRiche : ibid, 55

(63) H. Ehlers \& J. Moll : ibid, 261

(64) H.L.Caswell : J. Appl. Phys. 32, 105 (1961)

(65) [綜説] H. Mayer : "Structure and Properties of Thin Films" 225 (1959)

(66) [綜説] K. M. Greenland : J.Sci. Instr. 38, 1 (1961)

(67) W. Steckelmacher, et al : Vacuum 9, 171(1959),

(68) A.C. Trub : J.O.S.A. 46, 999(L) (1956)

(69) 森、高岡：応用物理 26, 443 (1957)

(70) 沢木、他：真空3，304 (1960)

(71) P. Giacomo et P. Jacquinot:J. Phys. Radium 13, 59A (1952) ; P. Giacomo : Rev. d'Opt. 35, 317 (1956) ; P. H. Lissberger \& J. Ring : Optica Acta 2, 42 (1955)

(72) G.R. Giedd \& M. H. Perkins : Rev. Sci. Instr. 31, 773 (1960)

(73) H. Schwarz: 7th Vac. Tech. Traus., 326(1960); Rev.Sci.Instr. 32, 194(1961)

(74) P. Lostis : Rev. d'opt. 38, 1 (1959) G. Sauerbrey : Zeits. Phys. 155 206(1959)

K. H. Bekrndt : 7th Vae. Tech. Trans., 87(1960)

(75) R. J. Gnaldinger : 5th Vac. Tech. Trans., 235 (1958), W.Rindner : Solid-State Electronics 1, 157 (1960)

(76) A. E. Ennos : J.O.S.A. 50, 14 (1960) 